\title{
Detailed mapping unit design based on soil-landscape relation and spatial variability of magnetic susceptibility and soil color
}

\author{
D.S. Siqueira ${ }^{\mathrm{a}, *}$, J. Marques Jr. ${ }^{\text {a }}$, G.T. Pereira ${ }^{\mathrm{b}}$, D.B. Teixeira ${ }^{\mathrm{a}}$, V. Vasconcelos ${ }^{\mathrm{c}}$, \\ O.A. Carvalho Júnior ${ }^{c}$, E.S. Martins ${ }^{\mathrm{d}}$ \\ a Department of Soils and Fertilizers, State University of São Paulo (UNESP), Research Group CSME - Soil Characterization for Specific Management, Jaboticabal, São Paulo, Brazil \\ ${ }^{\mathrm{b}}$ Department of Exact Sciences, State University of São Paulo (UNESP), Research Group CSME - Soil Characterization for Specific Management, Jaboticabal, São Paulo, Brazil \\ ' Department of Geography, University of Brasília (UNB), LSIE - Laboratory of Spatial Information Systems, Brasília, DF, Brazil

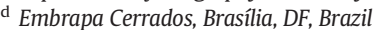

\section{A R T I C L E I N F O}

\section{Article history:}

Received 17 September 2014

Received in revised form 8 July 2015

Accepted 14 July 2015

Available online 13 August 2015

\section{Keywords:}

Split Moving Windows

Geostatistics

Attribute map

Pedometrics

\begin{abstract}
A B S T R A C T
The objective was to identify landscape areas with different patterns of variability using a statistic protocol with data of magnetic susceptibility (MS) and soil color that are covariate attributes of soil formation factors and processes. The studied area, of 380 ha, is located in Northeast of São Paulo State, Brazil. An amount of 86 samples was collected using $30 \mathrm{~m}$ intervals on the transect. At the transect sides, 150 samples were collected at $159 \mathrm{~m}$ intervals (a point each $2.5 \mathrm{ha}$ ). First the accuracy limits have been validated in the transect using the technique of Split Moving Windows - SMW. The limits identified in the transect were extrapolated to the sides using the contours of variability maps. The MS peaks SMW, for both depths, presented a correlation with the peaks of clay content $(\mathrm{r}=0.7 ; \mathrm{P}<0.01$ ), hue (varying from $0: 37 ; \mathrm{P}<0.05$ to $0.61 ; \mathrm{P}<0.01$ ) and Normalized Difference Vegetation Index-NDVI (varying from -0.25 to $-0.35, \mathrm{P}<0.05$ ). The errors of the MS spatial variability maps (6.22-11.85\%) were similar to the clay content ones (6:22 to $14: 16 \%)$. MS was more efficient in the compartmentalization of the landscape (identification of areas with different patterns of variability) than the hue determined by diffuse reflectance spectroscopy in Oxisols under the transition Basalt and ColluvialElluvial-Alluvial Deposits. The results of this study can lead to using an alternative strategy that is a mapping of soil attributes and identification of areas with different patterns of pedogenic iron oxide variability.
\end{abstract}

(c) 2015 Elsevier B.V. All rights reserved.

\section{Introduction}

The demand for detailed information about soil to assist agricultural and politic decision making is increasing (Delden et al., 2011). Detailed information can be used to support sustainable production. Current studies report the requirement for the developing of detailed indexes about global impacts of land use and management (Rockström et al., 2009).

The lack of experienced pedologists (mappers) (Demattê et al., 2007) and governmental resources (Bazaglia Filho et al., 2013) as well as discrepancy among proposed soil maps (Delarmelinda et al., 2011) detracts the spread of this type of information. The soil information provided by groundbreaking projects, such as RADAM Brasil (Brasil, 1981) and the Soil Survey Brazilian Service (Brasil, 1960) meets some requirements of Brazilian regions. However, in São Paulo State, this

\footnotetext{
* Corresponding author.

E-mail address: diego_silvasiqueira@yahoo.com.br (D.S. Siqueira).

URL's: http://csme.com.br/ (D.S. Siqueira), http://lsie.unb.br/lsie/ (V. Vasconcelos).
}

detailing level is not enough to attend the current demand of the agricultural industry. The forecasts point out a $15.7 \%$ raise in the domestic energy supply from sugarcane biomass (Brasil, 2012), which shows the need for more detailed maps to subsidize better production indexes.

For large territories, such as Brazil, Russia and China, the characterization and detailed design of soil mapping units (known as design a draft that defines boundaries for varied characteristic field locations) are hardly obtained. Among the causes is the natural variability of soil conditioning factors (geology, landscape shapes and others) (Legros, 2006). In order to minimize this problem, Soil Science experts manage the cumulative knowledge about soils to better approach the geovariability and pedodiversity. Their aim is to propose an alternative to the deficit of detailed information.

In the USA, soil mapping units were designed based on field variations and, subsequently, taxonomical units were also defined (Soil Survey Staff, 1975). In Brazil, the reverse process occurred. Firstly, taxonomical units were defined, with theoretical boundaries for the diagnostic attribute classification (soil color, base saturation, clay content, etc.). Based on these boundaries, the field unit designs were then established, so that the taxonomical unit does not match with the mapping unit. This problem 
may be worsened for places with detailed information requirements (Buol, 1990).

Some studies indicate that the solution to the mapping and taxonomical unit definition is in the previous pedodiversity evaluation (Ibáñez et al., 2009; Minasny et al., 2010). Others start from the importance of numerical classification models (Minasny and McBratney, 2007; Trangmar et al., 1985). In this case, the spatial distribution of soil attributes is considered during the boundary identification among soil taxonomical classes and in the detailed information supply about the soil genesis-landscape evolution relation (Hudson, 1992; Marcos, 1982). Our implicit knowledge about landscape models is the major cause of soil survey inefficiencies.

Hence, the understanding of this paradigm may be the base for the detailed design of soil units (Hudson, 1992; Swanson, 1993). In this way, the existing empiric models, based on the implicit knowledge, need to be converted into deterministic models, resulting in a better comprehension of cause-effect relations. In Brazil, the former Soil Committee belonging to the Soil Survey Brazilian Service (Brasil, 1960), currently named EMBRAPA Soils, had already mentioned implicit and explicit relations between soil and relief (Vidal-Torrado et al., 2005).

In this context of pedological study evolution, based on soil-landscape relation, the systematization of the multidisciplinary work proposal for ultra-detailed studies stands out, which is known as structural analysis of the pedological coverage. Such proposal is implemented in two stages: two-dimensional analysis (pedological survey performed perpendicularly to the contour lines) and three-dimensional analysis (using isodifferentiation curves in a defined area) (Ruellan et al., 1989). The hypothesis of this proposal is to integrate two-dimensional, conceptual (Dalrymple et al., 1968; Daniels and Hammer, 1992; Daniels et al., 1971) and mathematical models (Cunha et al., 2005; Pereira et al., 1996) with three-dimensional ones (Hammer et al., 1995; Montgomery, 2003) and geostatistical analyses (Isaaks and Srivastava, 1989; Rossi et al., 1992; Vieira, 2000; Zawadzki et al., 2005) helping in the area design based on field variability.

In this proposal type, there are two limiting factors: the computerrelated one and number of required samples. A great number of works are unfeasible because of the sample number (Demattê et al., 2007; McBratney et al., 2002). Thus, despite their quality, this kind of study presents high costs of time and resources as well as a large team for its performance (Lagacherie et al., 1995). As the computational technology advances in Soil Sciences (Hastie et al., 2001; McBratney et al., 2002), together with the use of magnetic susceptibility (MS), some of the limitations of two- and three-dimensional model integration can be solved. The MS and color are covariate attributes of soil formation factors and processes (Maher and Thompson, 1999), showing a representativeness of physical, chemical and mineralogical attributes (Siqueira et al., 2010b; Torrent et al., 2007; Verosub and Roberts, 1995; Zawadzki et al., 2012).

Therefore, the objective of this research was to identify landscape areas with different patterns of variability (detailed mapping unit design) using a statistic protocol with data of magnetic susceptibility (MS) and soil color that are covariate attributes of soil formation factors and processes.

\section{Material and methods}

\subsection{Location, area characterization and sampling scheme}

The studied area, of 380 ha, is located in the São Paulo State Northeast, in Guatapará Town, Brazil (Fig. 1a). The geographical coordinates are $21^{\circ}$ $28^{\prime} \mathrm{S}$ and $48^{\circ} 01^{\prime} \mathrm{W}$, at $600 \mathrm{~m}$ of maximum altitude. According to the Thornthwaite (1948) classification, the local climate can be defined as $\mathrm{B} 1 \mathrm{rB}^{\prime} 4 \mathrm{a}^{\prime}$, humid mesothermic with a small water deficiency, with a summer evapotranspiration $70 \%$ lower than the annual one.

The natural vegetation was composed of sub-deciduous tropical forest; however, it has been consisted of a sugarcane field with mechanized harvesting for more than 10 years. The cultivated varieties are SP87-365, SP83-2847 and RB 925345. The area is inserted in the geomorphological unit of the Western Paulista Plateau, in which source material is related to the Basalt transition, São Bento Group, Serra Geral Formation, Colluvial-Elluvial and Alluvial Deposits (Geobank, 2012; IPT, 1981) (Fig. 1d). That kind of transition represents around 44,000 ha in São Paulo State, Brazil (Siqueira et al., 2014). The soil map (scale of 1:12,000) records the occurrence of Eutroferric Red Latosol clay texture (Brazilian classification: LVefarg; Soil Taxonomy: Typic Eutrudox), Dystroferric Red Latosol clay texture (Br. Class.: LVdf; Soil Taxonomy: Typic Hapludox), Dystrophic Red Latosol medium texture (Br. Class.: LVd; Soil Taxonomy: Typic Hapludox) and Dystrophic RedYellow Latosol medium texture (Br. Class.: LVAd; Soil Taxonomy: Typic Hapludox) (Fig. 1e). Clay texture: $350-600 \mathrm{~g} \mathrm{~kg}^{-1}$ of clay, and medium texture: $150-350 \mathrm{~g} \mathrm{~kg}^{-1}$ of clay (Embrapa, 2006). The $\mathrm{Fe}_{2} \mathrm{O}_{3}$ contents varied from 200 to $20 \mathrm{~g} \mathrm{~kg}^{-1}$ from the top ( $590 \mathrm{~m}$ ) to the bottom hill (520 m).

Four production environments were identified: A, B, C and D (Fig. 1f). The sugarcane environment map (which is considered a technical survey) team based on inherent characteristics from each soil (taxonomical survey, Fig. 1e), taking into account soil factors and potential sugarcane yield.

Using the Digital Elevation Model (Fig. 1b), surface water flow simulation (Fig. 1c) and field observations (Fig. 2a), a $2508 \mathrm{~m}$ transect was identified from the top to the foothill, following the slope smoothest side (Fig. 2b). In order to identify the field boundaries, the changes along the slope were observed (Dalrymple et al., 1968) (Fig. 2b). Six compartments were identified by the conceptual model in the field: top, half slope, shoulder, slope, transportation foothill and deposition foothill. Apart from these, geomorphometric compartments were also identified according to the model proposed by Vasconcelos et al. (2012) (Fig. 1g). This method aims to minimize subjectivity in the compartment identification by conceptual landscape models and may be applied at different scales.

We used information from the mission "Shuttle Radar Topography Mission" (SRTM) with horizontal resolution of $90 \mathrm{~m}$ and vertical accuracy of approximately $15 \mathrm{~m}$. SRTM data were downloaded from Hydrological data and maps based on SHuttle Elevation Derivatives at multiple Scales (HydroSHEDS). This product was developed from World Wide Fund for Nature (WWF), United States Geological Survey (USGS) with the supporting of other institutions. The images present filter treatments and drainage corrections (Lehner et al., 2006). From the SRTM four images were generated for the following slope curvatures: longitudinal, cross-section, minimum and maximum. Formulations for obtaining curvatures can be found in the work of Vasconcelos et al. (2012). These four images of curvature of land were united to establish a geomorphometric signature, which allowed not only to characterize the relief in which it is inserted, plus also the intensity of the landform (e.g. in Fig. $1 \mathrm{~g}$ a intensity increases the concavity of the form RRc1 to RRc4).

A number of 86 samples were collected along the transect on the top hill at $30 \mathrm{~m}$ intervals and, at the transect sides, 150 samples were collected at $159 \mathrm{~m}$ intervals (one point each $2.5 \mathrm{ha}$ ) (Fig. 1h). At these points, soil samples were collected using an auger at $0.00-0.25 \mathrm{~m}$ and $0.25-0.50 \mathrm{~m}$ depths, which are the sample depths used in the sugarcane industry in São Paulo State. Marques and Lepsch (2000) reported that results based on horizontal and vertical soil variability up to $0.8 \mathrm{~m}$ depth may be used in pedology studies. Cunha et al. (2005) confirmed the representativeness of that layer in Oxisols on São Bento Group, Serra Geral Formation Basalts and Sandstone, Bauru Group, Adamantina Formation. The low vertical variability from the magnetic susceptibility and physical, chemical and mineralogical soil attributes from Basalt Oxisols also has been reported in other works (Berquó et al., 2004; Camargo et al., 2014; Matias et al., 2013).

\subsection{Laboratory analysis}

\subsubsection{Soil characterization}

Following the proposed methodology by Embrapa (1997), a particle size analysis was performed from the collected samples, using the 

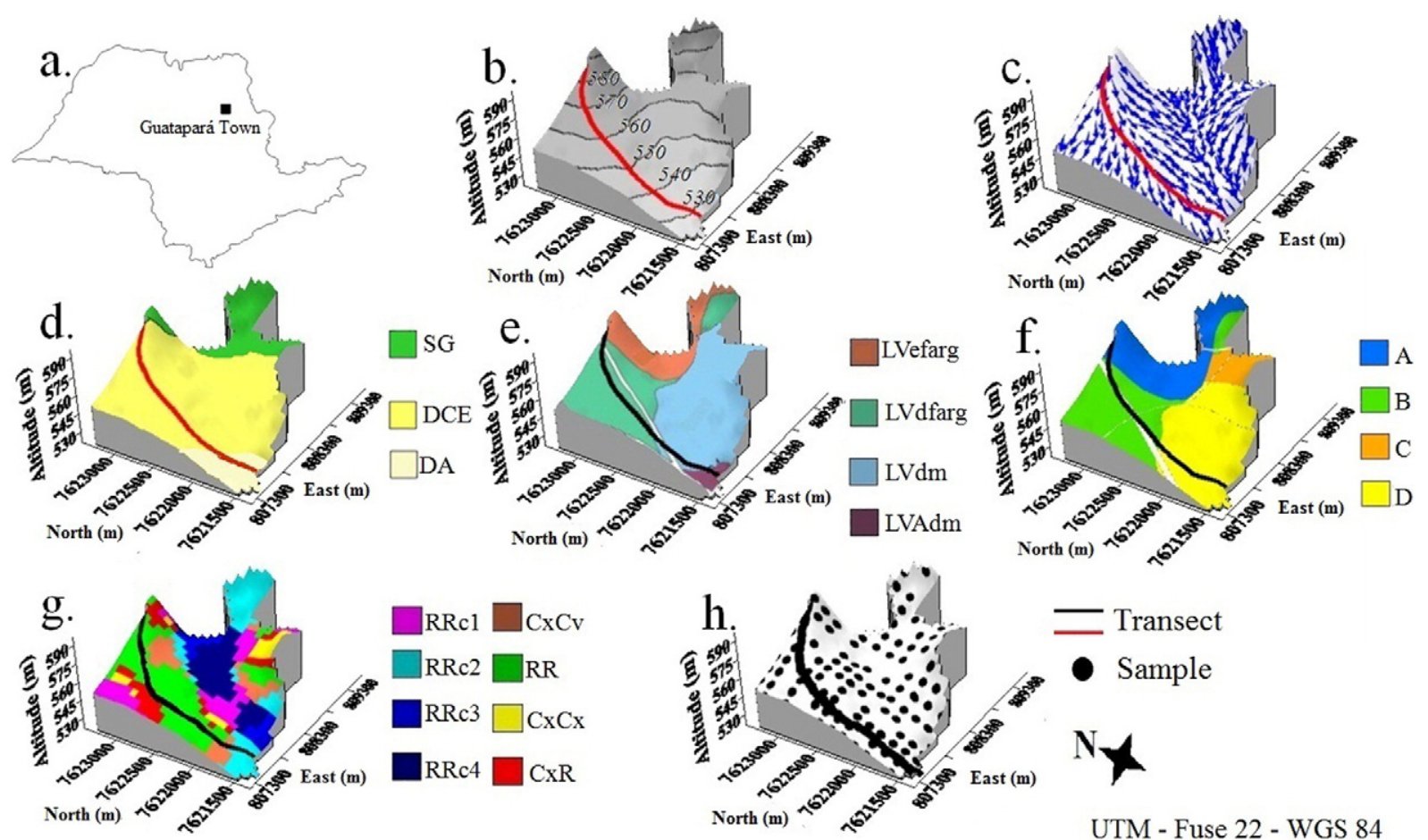

. 1. Location of the study area (a); digital elevation model (b); simulation of surface water (c); geological map, scale 1:500,000 (d) (SG - Basalt, São Bento Group, Serra Geral Formation;

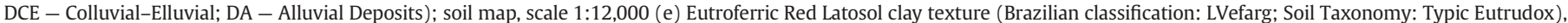

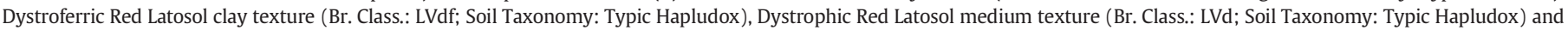

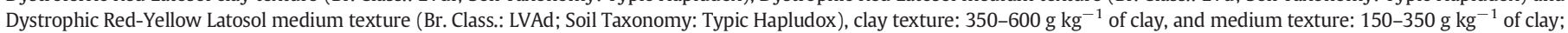

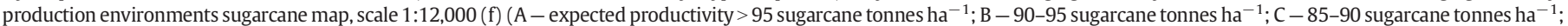

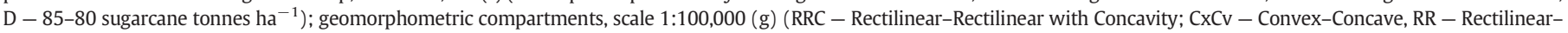
Rectilinear; Cx-Cx - Convex-Convex; CxR - Convex-Rectilinear); and sampling points (h) (86 points in transect and 150 points in the area of 380 ha).

pipette method, a $\mathrm{NaOH} 0.1 \mathrm{~mol} \mathrm{~L}^{-1}$ solution as a chemical dispersant, and the low rotation mechanical stirring for $16 \mathrm{~h}$.

The $\mathrm{pH}$ was potentiometrically determined using a 1:2.5 soil:water proportion. Calcium, magnesium, potassium and available phosphorus were extracted by the ion exchange resin method (Raij et al., 2001). The exchangeable acidity $\left(\mathrm{Al}^{3+}\right)$ and organic carbon were obtained following the methods described by Raij and Zullo (1977) and Embrapa (1997), respectively. The sum of bases (SB), cation exchange capacity (CEC) and $\mathrm{V} \%$ were calculated from values of $\mathrm{H}+\mathrm{Al}$ and bases.

The total iron $\left(\mathrm{Fe}_{2} \mathrm{O}_{3}\right)$ was determined after digestion in $\mathrm{H}_{2} \mathrm{SO}_{4}$ $1: 1$, for $\mathrm{Al}_{2} \mathrm{O}_{3}$ and $\mathrm{Fe}_{2} \mathrm{O}_{3}$, followed by an alkaline dissolution for $\mathrm{SiO}_{2}$, according to Embrapa (1997). The characterization of goethite and hematite by X-ray diffraction (XRD) was performed after treatment of the clay according to the procedure described in Kämpf and Schwertmann (1982). The average diameter of the crystal (DMC) was calculated from the width at half height (AML) and the position of the reflections of the minerals using the Scherrer equation (Schulze, 1984). The reason kaolinite / (kaolinite + gibbsite) $-[\mathrm{Kt} /$ $(\mathrm{Kt}+\mathrm{Gb})]$ was calculated using the areas reflexes $\mathrm{Kt}(001)$ and $\mathrm{Gb}(002)$.

The magnetic susceptibility (MS) was obtained from ADFE (air dried fine earth) in a Bartington MS2 equipment connected to a Bartington MS2B sensor. The evaluation was performed at low frequency $(0.47 \mathrm{kHz})$ (Costa et al., 1999; Dearing, 1994). According to these authors, the double frequency measurements (high $-4.7 \mathrm{kHz}$ and low) must be used for qualitative studies to indicate simple and multiple dominium minerals. In the case of a single reading, the low frequency is indicated for more accurate results (Bartington, 2013).

The evaluations for diffuse reflectance spectrums were performed from the $0.00-0.25 \mathrm{~m}$ depth samples using a Lambda 950 laboratory sensor with an $80 \mathrm{~mm}$ integrating sphere. An amount of $0.5 \mathrm{~g}$ of ADFE was ground in agate mortar, until it reached steady coloration, and poured into a $16 \mathrm{~mm}$ cylinder sample holder. The reflectance values were obtained through spectrophotometer with an $80 \mathrm{~mm}$ integrating sphere, each $1 \mathrm{~nm}$, with an integration time of $0.2 \mathrm{~s}$ and scan interval of 380 to $780 \mathrm{~nm}$. After the spectrum determinations, the three stimulation frequency XYZ was defined according to the Comisión Internacional de L'Eclairage-CIE (Wyszecki and Stiles, 1982), from which the Munsell hue and chroma values were deducted by using Munsell Conversion 6.4 version, as described by Viscarra Rossel et al. (2010) and Barrón et al. (2000).

\subsubsection{Plant characterization}

The sugarcane yield history that was expressed in tons of culms per hectare (TCH) was evaluated from the last three years (2009; 2010 and 2011). The total reducing sugars (TRS) were evaluated in three representative points (composed of subsamples) from the found mapping units. The mapping unit I is composed of six representative subsamples of 31.50 ha; II, of 13 subsamples of 76.98 ha; and III, of 13 subsamples of 185.05 ha. TCH and TRS were determined following Consecana's (2003) methodology. Those sugarcane attributes are very important for the sugar and alcohol industry control, especially concerning the industrial process efficiency, sugarcane payment which is based on the sucrose content, and cane maturation stage.

The vegetation index was determined for each sampled point on the transect and sample grid using the NDVI (Normalized Difference Vegetation Index) calculation. The NDVI values were calculated after a radiometric transformation (Chander and Markham, 2003) and atmospheric correction (Zullo, 1994), through LANSAT 5 TM satellite images, which are available for free at INPE <http://www.dgi.inpe.br/ CDSR/>. These images were obtained in March 2009, 2010 and 2011, with a $30 \times 30 \mathrm{~m}$ resolution. In order to eliminate the temporal variability and different sugarcane stages and varieties, an information standardization was performed for the three years (Eq. (1)). 


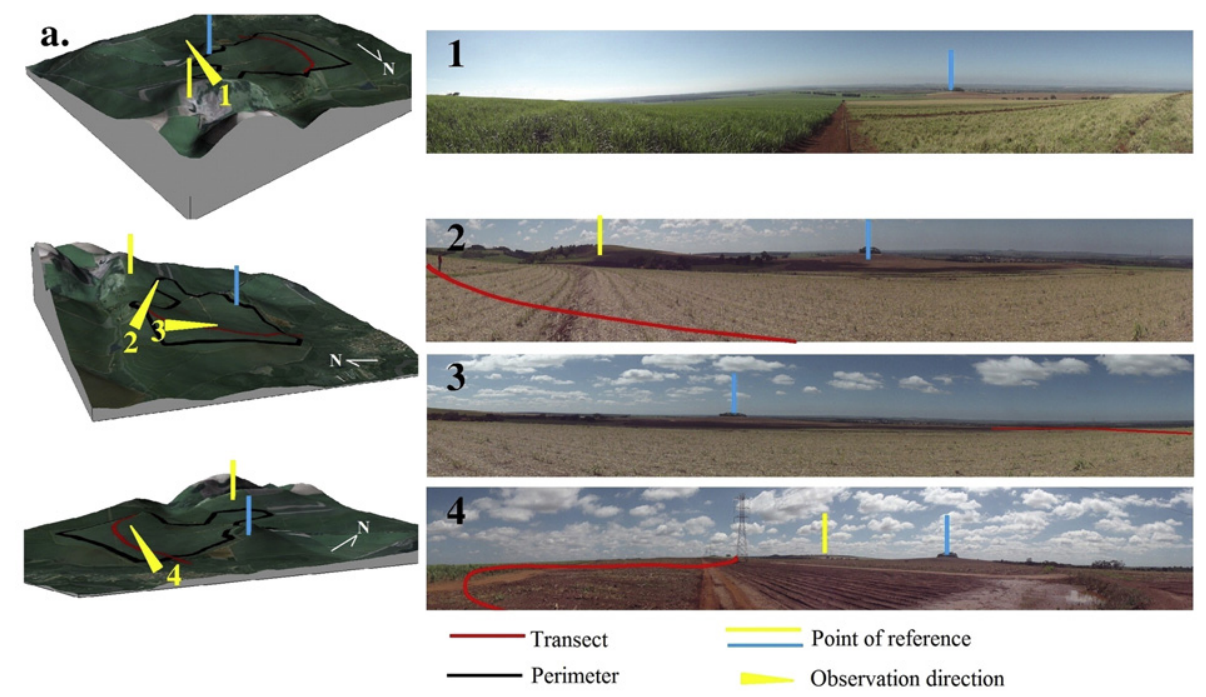

b.

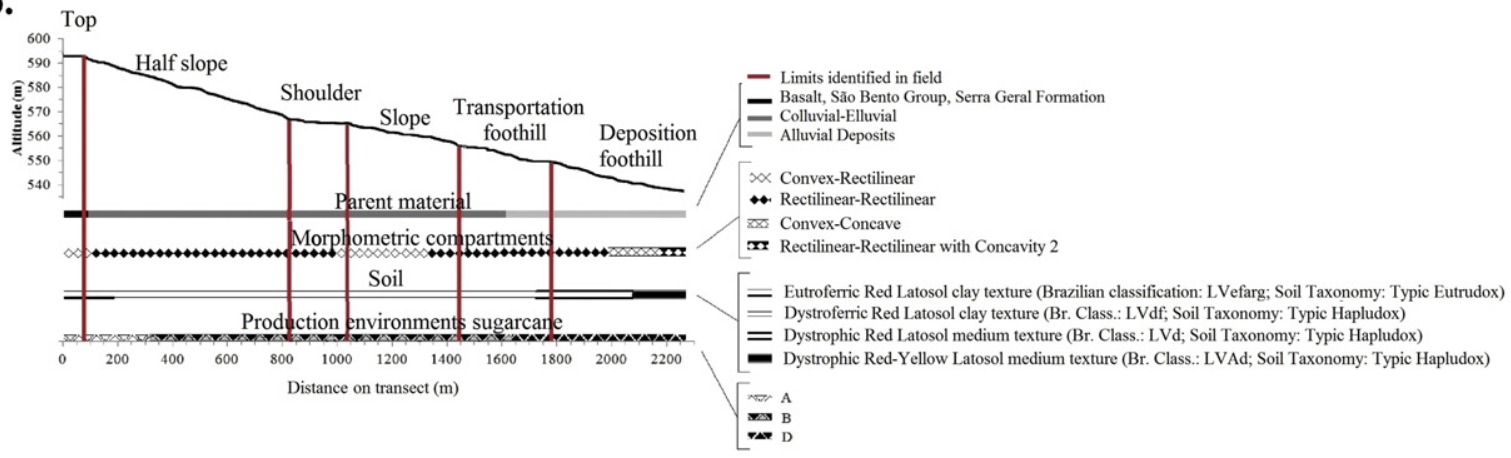

Fig. 2. Landscape characterization (a); altimetric profile and real and conceptual field boundaries (b).

$\mathrm{NDVI}_{i y}=\left(\mathrm{NDVI}_{i y}-\mathrm{NDVI}_{\text {medium }}\right) / \sigma$,

where $\mathrm{NDVI}_{i y}$ is $\mathrm{NDVI}$ value for $i$ year at $y$ point; $\mathrm{NDVI}_{\text {medium }}$ is the medium NDVI value for $n$ years at $y$ point; and $\sigma$ is NDVI standard deviation of $n$ years at $y$ point. The NDVI data analysis was performed with standardized data residue.

\subsection{Data analysis}

\subsubsection{Two-dimensional analysis}

In order to validate the landscape compartment boundaries identified in the field according to the conceptual model of slope segments, the Split Moving Windows (SMW) analysis was performed (Choesin, 2001; Cunha et al., 2005; Pereira et al., 1996). The SMW was carried out from the 86sample results from the transect. This evaluation is based on statistical dissimilarity calculations among sample point group sequences also collected in sequence on the transect. Thus, the area boundaries are accurately identified with varied homogeneity standards of soil attributes (Webster, 1973). Firstly, a number of "n" points are chosen, which are called "Window". This window is then consecutively "moved", from the beginning to the end of the transect, point by point. For each position on the transect, the window is divided into two parts (two windows), where the average between them are calculated and compared. These comparisons are made by using the " $\mathrm{t}$ " statistics and the value is plotted in a graphic ("t" statistics versus distance) (Fig. 3).

The window length can be determined through the autocorrelation analysis using the original attributes (Webster, 1973, 1978). The other parameter is the Mullion index, that is the prefixed distance between those two windows. In the generated graphic, the highest peaks correspond to the more elevated " $t$ " statistics value, which indicate the mathematical boundaries among areas with different soil attribute variations.

The $t$ statistic calculation is given by Eq. (2):

$t=\frac{\bar{x}_{1}-\bar{x}_{2}}{S_{p} \sqrt{\frac{1}{n_{1}}+\frac{1}{n_{2}}}}$,

where $\bar{x}_{1}$ and $\bar{x}_{2}$ are the sample means from the two windows ( $\mathrm{n}_{1}$ and $\mathrm{n}_{2}$ ); $\mathrm{Sp}$ is the combined estimate of the common standard deviation, given by Eq. (3).

$S_{p}=\frac{\left(n_{1}-1\right) S_{1}+\left(n_{2}-1\right) S_{2}}{n_{1}+n_{2}-2}$

where $\mathrm{S}_{1}, \mathrm{~S}_{2}, \mathrm{n}_{1}$ and $\mathrm{n}_{2}$ are the standard deviations and samples size from those two predetermined windows, respectively (Fig. 3). In this study, windows of 20 observations and Mullion with range of of two or ones points were used. In order to verify the association level of the SMW results for the varied attributes, Pearson correlations were performed.

Such approach is restricted to the two-dimensional field boundaries and, for the comprehension of their extension in the landscape (bilaterality), a three-dimensional emphasis of the pedosphere continuum is necessary (Hall, 1983). Thus, the pedological coverage analysis was split into two steps: two-dimensional (conceptual field boundary validation through SMW); and three-dimensional (mathematical boundary extrapolation through SMW for the transect sides using the spatial variability map isolines) (Fig. 4). 


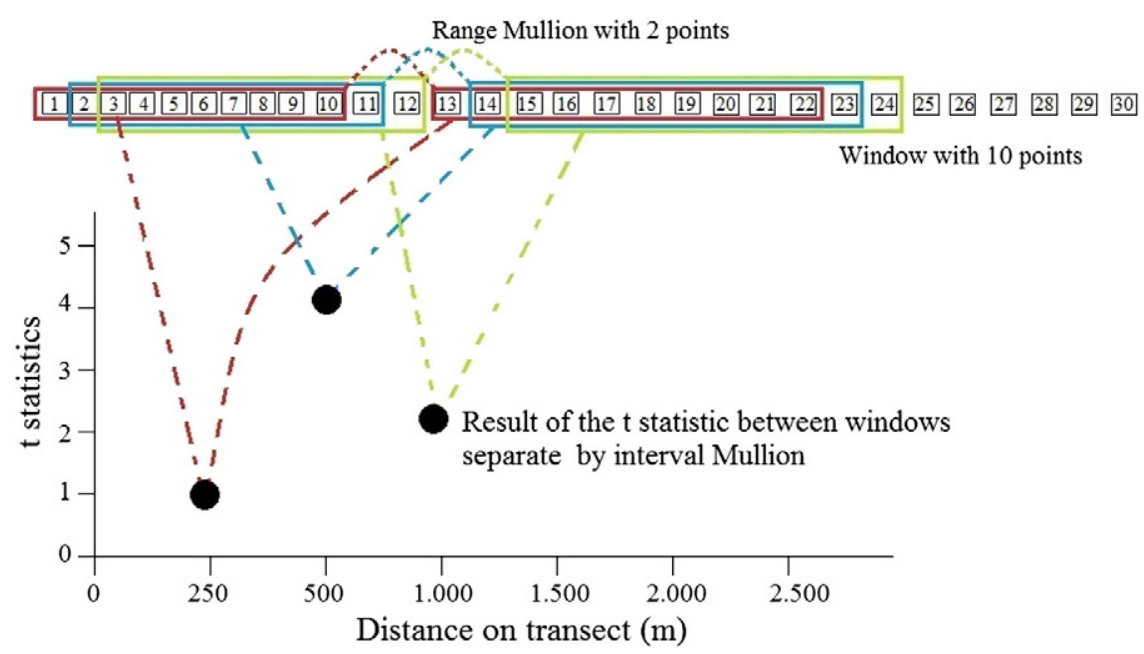

Fig. 3. Scheme operation of the "Split Moving Windows" (SMW) analysis with a window of 10 points and Mullion interval with 2 points in the transect.

\subsubsection{Three-dimensional analysis}

The different variability classes (Fig. 5b1, b2, b3, b4) were confronted with the SMW peaks. The isolines with greater potential to represent the continuous variability along the landscape were chosen (Fig. 5c).

This process is repeated for various soil attributes. After choosing the isoline with greater representativeness (Fig. 5d), the design of the mapping unit was performed (Fig. 5e). It is highlighted that, at the moment of the most representative isoline choice, there are two important issues to be considered: the design implementation operability and user applicability.

The experimental variogram modeling followed the principles established by the intrinsic hypothesis (Isaaks and Srivastava, 1989). The experimental variogram was determined through the semi-variance calculation based on the distance between the 116 collected samples on the sample grid.

The choice of the variogram adjusted model was based on the determination coefficient $\left(R^{2}\right)$ and parameters linear $(a)$ and angular (b) coefficients, obtained from the cross-validation model (Vieira, 2000). At the cross-validation, each observed value is removed and subsequently estimated using parameters from the adjusted model and observed values from closer samples.

The relative error of the spatial distribution map was analyzed through the "relative root mean square error" (RRMSE) (Eq. (4)) (Li and Heap, 2008). The advantage of this method is its practicality when comparing the varied attribute maps. The variogram modeling was performed considering 116 points and, for the RRMSE calculation, 40 points.

RRMSE $=\left[\frac{1}{n} \sum_{i=1}^{n}\left(\left[p_{i}-o_{i}\right] / o_{i}\right)^{2}\right]^{1 / 2}$,

where $n$ is the number of observations, $p_{i}$ is the predicted value of an $i$ point, and $o_{i}$ is the observed value at $i$ point.

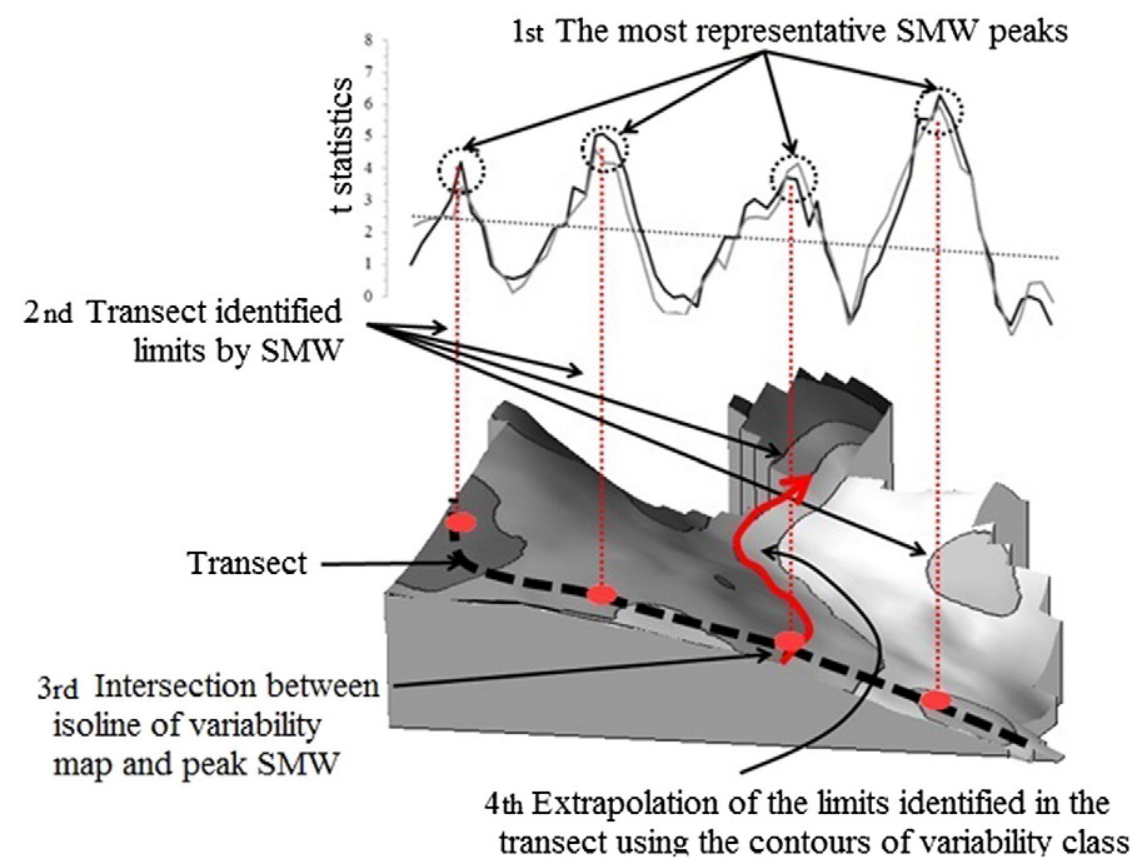

Fig. 4. Diagram showing the mathematical boundaries found by the "Split Moving Windows" (SMW) analysis and isolines of the spatial variability maps. 
a.

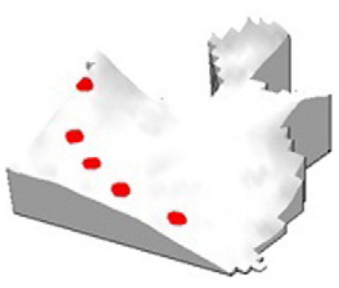

b.
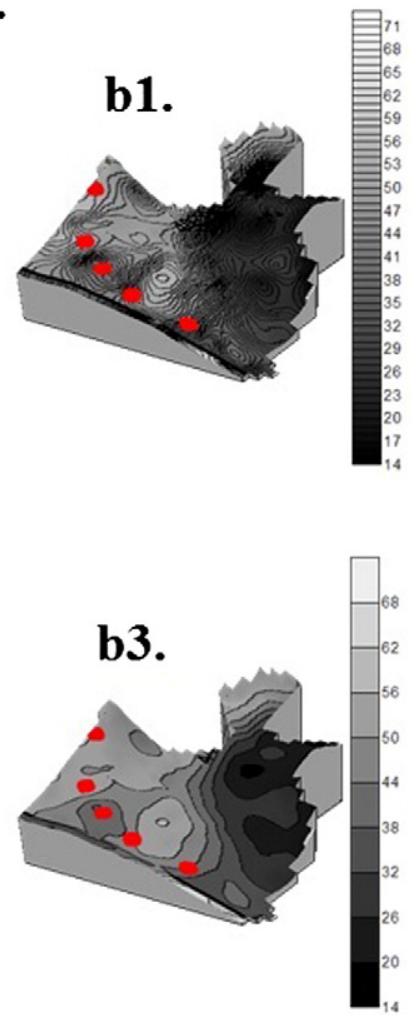

d.

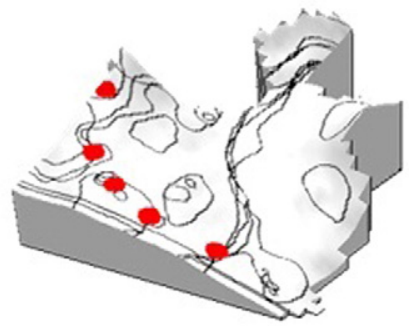

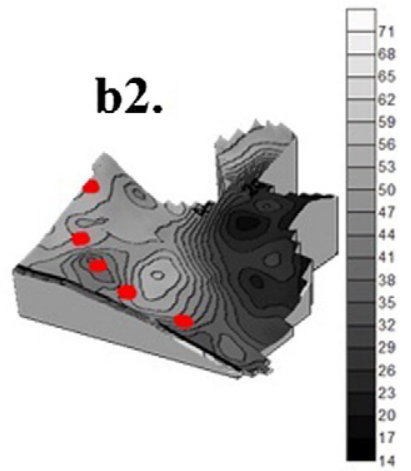

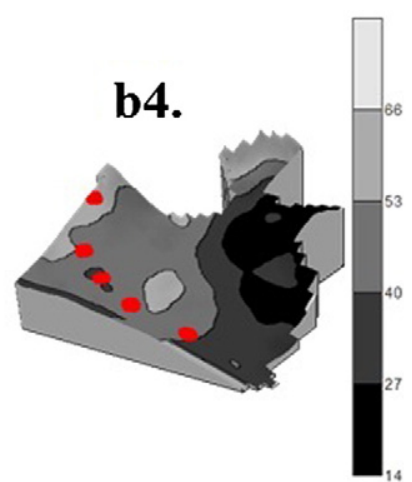

e.

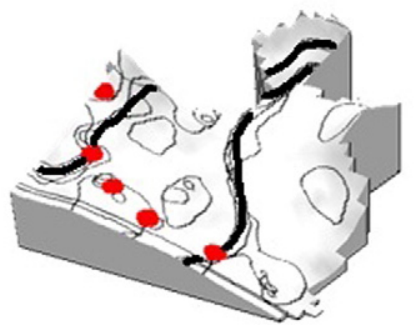

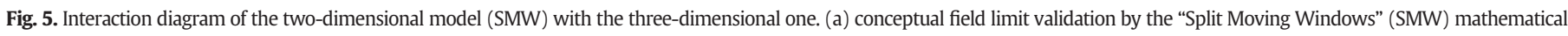

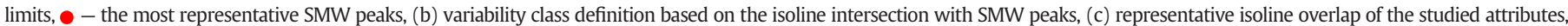
(d) selection of isolines with greater spatial continuity, (e) mapping unit design with variability control.

\section{Results and discussion}

\subsection{Two-dimensional analysis: soil transect}

The compartment boundaries identified in the field, according to the conceptual model, were top/half slope at $75 \mathrm{~m}$, half slope/shoulder at $825 \mathrm{~m}$, shoulder/slope at $1025 \mathrm{~m}$, slope/transportation foothill at $1440 \mathrm{~m}$ and transportation foothill/deposition foothill at $1775 \mathrm{~m}$. The SMW results show that there are five emphasized peaks: the 1st at $150 \mathrm{~m}$; 2nd at $675 \mathrm{~m}$; 3rd at $1075 \mathrm{~m}$; 4th at $1375 \mathrm{~m}$; and 5th at $1825 \mathrm{~m}$. The 2nd, 3rd and 4th peaks indicate the presence of different compartments in areas that were considered homogeneous, i.e., they presented the same soil class and cultivation environment (Fig. 6a). This denotes the possibility to refine and update the compartments that already exist. Boughton et al. (2006) observed similar results in a landscape that is considered homogeneous, what confirms that such technique is quite safe and may be used to help in the boundary discrimination of environmental and pedogeomorphic processes.

The correlation among the SMW results indicates that there are different association degrees among soil, plant and relief attributes.
There was a correlation with the altitude and MS for the $0.00-0.25 \mathrm{~m}$ depth $(\mathrm{r}=-0.29 ; \mathrm{P}<0.05)$ and base saturation for both depths $(\mathrm{r}=-0.30 ; \mathrm{P}<0.05)$. The MS, for both depths, presented a correlation with the clay content $(\mathrm{r}=0.7 ; \mathrm{P}<0.01$ ), hue (ranging from 0.37 ; $\mathrm{P}<0.05$ to $0.61 ; \mathrm{P}<0.01$ ) and NDVI (ranging from $-0.25 ; \mathrm{P}<0.05$ to $-0.35 ; \mathrm{P}<0.05)$. This shows that there is a concordance among the variation causes along the slope and, also, that the conceptual model field boundaries and MS, which are covariate of the other studied attributes, are sensible to those causes.

About using NDVI index, innovation of the proposal is the use of NDVI data as input information for the analysis of SMW. This allows the plant response being used to validate the relationship of cause and effect between soil and plant. Although its effectiveness and practicality, the SMW technique is underused in soil science. The proposed joint use of SMW and NDVI data to validate variability of compartments elaborated by other techniques is unprecedented and can be very useful for work in forestry area and ecophysiology studies (Zawadzki et al., 2005), focusing on soil-forest relationship, for example.

Even if the geological map is low-level detailed (1:500,000), it shows the occurrence of the 1 st to the 5 th peaks. The geomorphometric 


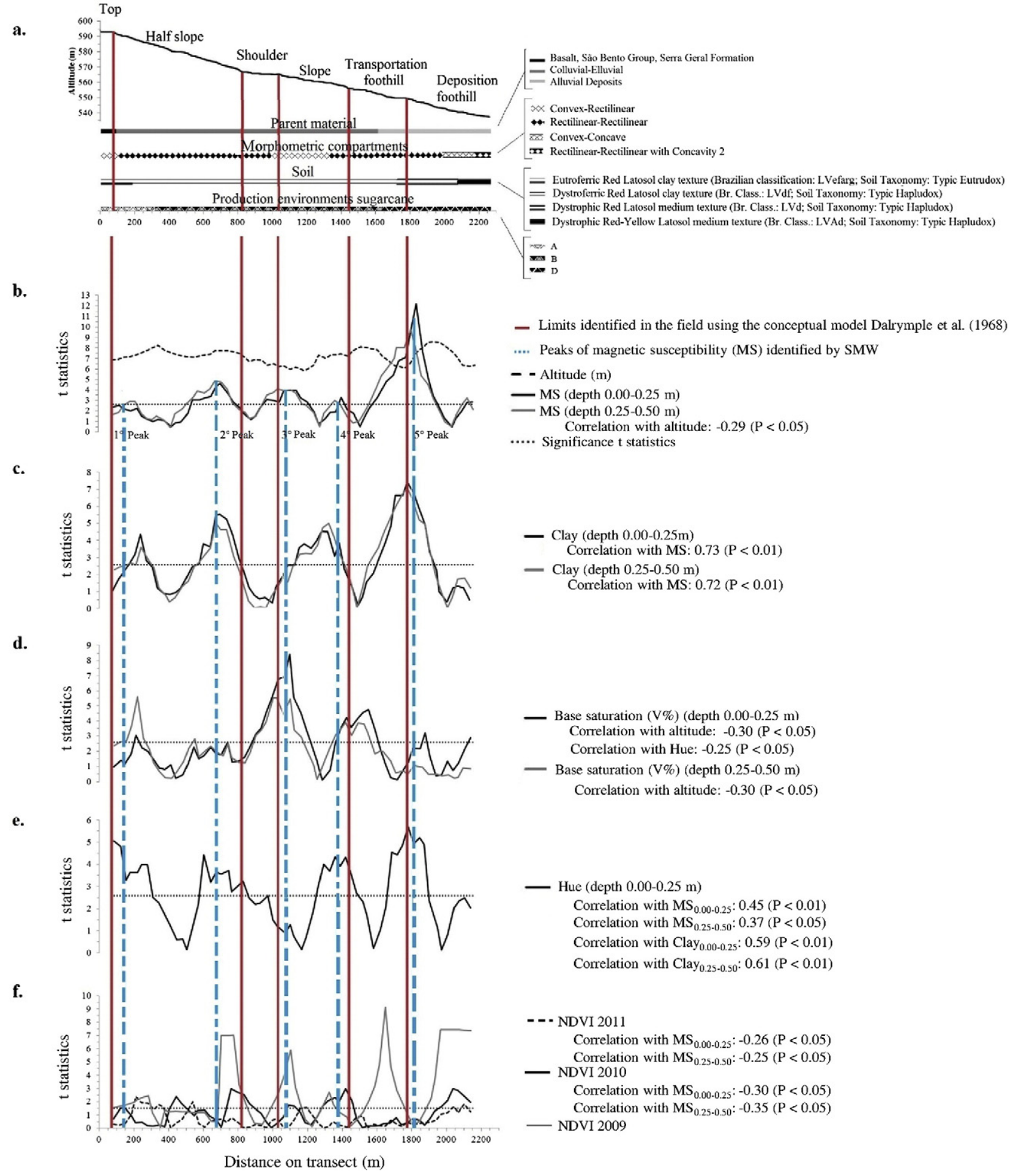

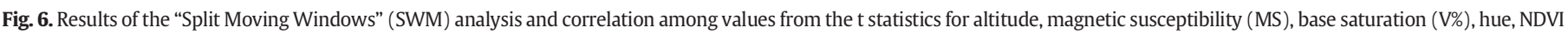
(Normalized Difference Vegetation Index) for the years 2009, 2010 and 2011 along the transect with $30 \mathrm{~m}$ spaced points.

compartments, which are detailed $(>1: 20,000)$ exhibit the occurrence of the 1 st to the $3 r d$ peaks. This preliminary analysis indicates that the variability in this mapping unit may have been more influenced by the geological compartments than the geomorphometric ones. The greatest part of the pedological studies may properly elucidate only issues related to the soil spatial distribution from a previous understanding of the landscape as a whole when considering the source geological materials (Vidal-Torrado et al., 2005).
The proximity of the field boundaries to the SMW peak analysis indicate that the conceptual model described by Dalrymple et al. (1968) may be used as a helping tool to identify the boundaries among areas with different variation patterns. Although the conceptual models (Dalrymple et al., 1968; Daniels and Hammer, 1992; Daniels et al., 1971) are useful to explain the acting processes along the slope, they are little utilized because of their tacit character (Hudson, 1992; Swanson, 1993). 
One of the solutions is related to the competence of the field mapping designers on soil-landscape relations (Legros, 2006). Thus, the SMW mathematization of these boundaries may solve some of those limitations. This suggests, for instance, that the union of conceptual and mathematical models is an useful field tool for studies on soil genesis and mapping. Even in flat lowland areas, the pedology-geomorphology relations do exist and may be foreseeable by the field mappers (Berg et al., 1987). Such kind of approach was also used for the understanding of the interdependence of physical and mineralogical frictions in an ultra-detailed level (Camargo et al., 2008b).

Despite being seemingly simple in comparison to non-parametric methods more robust and known in soil science, when combined with spatial variability, $t$ test becomes a powerful tool for identifying limits in the paradigm of soil-landscape relationship.

Few works explore the applicability of traditional methods associating them with spatial vision. This reinforces the technics SMW originality and the importance of its disclosure as an alternative tool geostatistics and fuzzy logic, for example, to identify areas with different patterns of variability and landscape in transects based on the works of Dalrymple et al. (1968) and Daniels et al. (1971).

Non-parametric methods as an example the Moving Multivariate Split Windows (SMWM) with the Mahalanobis distance ( $\left.D^{2}\right)$ (Webster, 1978) can also be used in studies on the transection. Both SMWM as SMW based on the concept of two sliding windows and a gap between them, called Mullion. But while the SMW uses the t statistic to identify the differences, the SMWM uses the distance D2 of Mahalanobis. The advantage of using the Mahalanobis distance is related to the improvement of the expression of the peaks. Thus, we understand that future works using the technique SMWM are complementary to this the proposal using SMW.

The clay content (Fig. 6c) and MS (Fig. 6b) showed peaks with a better expression of the field boundaries for both depths. For those regions from 500 to $800 \mathrm{~m}$ and from 1400 to $1600 \mathrm{~m}$ high, 2nd and 4th peaks respectively, the base saturation (Fig. 6d) and hue (Fig. 6e) did not present $t$ statistical values that composed well expressed peaks. Thus, the isolated interpretations of such attributes for the 2nd and 4 th peak regions may compromise the field boundary validation.

Based on the analysis of the results, it is suggested that the relief compartmentalization, using conceptual models, be either validated by the source material covariate attributes or related to the soil forming processes, like the MS. Studies by Santana (1984) and Curi (1983) inform that the use of the clay fraction MS indicates a greater consistency in the gradation variation along a toposequence than in the soil color or mineralogy. Goluchowska (2001) and Kapicka et al. (2001) reported that the MS magnitude, measured in the soil, depends on the variability of the source material and pedogenic processes.

Our results, like those obtained by Siqueira et al. (2010b), show that the MS has the potential for a detailed characterization of hypoferric soils (contents of $\mathrm{Fe}_{2} \mathrm{O}_{3}<80 \mathrm{~g} \mathrm{~kg}^{-1}$ ), even with low $\mathrm{Fe}_{2} \mathrm{O}_{3}$ contents $\left(<40 \mathrm{~g} \mathrm{~kg}^{-1}\right)$. Marques et al. (2014), when working with soils that presented $\mathrm{Fe}_{2} \mathrm{O}_{3}$ contents of $18 \mathrm{~g} \mathrm{~kg}^{-1}$, from the Sandstone, Bauru Group, reports that both the diffuse reflectance spectroscopy, and magnetic susceptibility have the potential to be used as diagnostic attributes for identification of areas with different potential production on. These results suggest that those studies that are performed in similar environments should attempt to this fact in order to avoid misconceptions.

Both the sensibility of the current sensors and MS quantitative character allow the reassessment of the conclusions of studies on that subject. In the past, researchers concluded that, although the MS is much associated with $\mathrm{Fe}_{2} \mathrm{O}_{3}$ contents and soil color, its application would not be enough to distinguish Oxisols with low $\mathrm{Fe}_{2} \mathrm{O}_{3}$ contents $\left(<40 \mathrm{~g} \mathrm{~kg}^{-1}\right)$ from yellow ones, so that other criteria should be used to validate the soil separation (Resende et al., 1988a).

Regarding the landscape conceptual model, the SMW results indicate that, for the studied region, the model described by Dalrymple et al. (1968) was effective for the identification of the field boundaries. Other authors (Cunha et al., 2005) used the SMW for the validation of the conceptual model reported by Daniels et al. (1971) for Oxisols under the Basalt Transition, Serra Geral Formation - Sandstone, Bauru Group. The MS was also utilized for the validation of the field boundaries and design of detailed mapping units in this same geological transition (Matias et al., 2013). This kind of relation between the geological compartment and eligible landscape model is important for the correct definition of the field boundaries.

\subsection{Three-dimensional analysis: variability maps and digital elevation model}

The geostatistical analysis, for the boundary identification and design of mapping units, was performed in the second stage of this study. The parameters of the variogram models adjusted to the soil and plant data are presented in Table 1.

The most observed variogram model was the spherical for $68 \%$ of the studied attributes, followed by the exponential one (25\% of the observations) and the Gaussian one ( $7 \%$ of the observations). The spherical model is adjusted to those attributes that show abrupt variations throughout the landscape. Such variations may be related to the types of source material (Fig. 1d) (Rauch, 2011), relief (Fig. 1b) (Kravchenko and Bullock, 2002; Siqueira et al., 2010a) and soil (Fig. 1e) (Montanari et al., 2012). These observations are the first evidence of a possible relation among these factors and the detailed and ultra detailed characterization of the spatial variability and definition of mapping units (Vidal-Torrado et al., 2005).

In the $0.00-0.25 \mathrm{~m}$ depth, the attributes that showed a strong spatial dependence degree (SDD < 25\%) (Cambardella et al., 1994) were: cation exchange capacity (CEC), MS, total sand (TS), clay content, sum of bases (SB) and base saturation (V\%). The attributes $\mathrm{pH}$, hue, silt, $\mathrm{H}+\mathrm{Al}$, value, organic matter $(\mathrm{OM})$ and available phosphorus $\left(\mathrm{P}_{\text {avail. }}\right)$ presented a moderate SDD $(25 \%<$ SDD $<75 \%)$. In the $0.25-0.50 \mathrm{~m}$ depth, the attributes that showed a strong spatial dependence degree were: $\mathrm{pH}$, MS, TS and silt.

The attributes $\mathrm{CEC}, \mathrm{SB}, \mathrm{P}_{\text {avail }}, \mathrm{H}+\mathrm{Al}, \mathrm{OM}$ and $\mathrm{V} \%$ showed a moderate SDD. The plant attributes presented a moderate SDD in the three analyzed years. The SDD values of the MS and hue indicate that the MS is more influenced by the landscape compartment than by the soil hue, so that the MS presents more potential for the refinement of the precision boundaries.

As the isolines of the variability maps will subsidize the extrapolation of the boundaries indicated by the SMW peaks, it is essential that the variogram models are properly adjusted. This stage is strictly related to the researcher experience (Franzen et al., 2006). The choice of the variogram model, as well as its parameter adjustment, is a little subjective, as it is the conceptual model. In order to reduce this kind of interference, tests of adjustment verification are recommended. The most used ones are the $\mathrm{R}^{2}$ (Gallardo and Paramá, 2007; Guedes Filho et al., 2010) and cross-validation (Guedes Filho et al., 2010; Lu et al., 2012; Vieira et al., 2010).

With the exception of $\mathrm{P}_{\text {avail }}$ ( $\left.0.00-0.25 \mathrm{~m}\right), \mathrm{V} \%$ and MS $(0.25-0.50 \mathrm{~m})$ that showed small deviations from the angular coefficient, the other studied attributes had good adjustments and presented the angular (a) and linear (b) coefficients close to 0 and 1 , respectively.

The cross-validation results are commonly expressed in terms of the linear and angular coefficients, which are obtained from a regression among the observed values and those estimated by the adjusted variogram (Vieira et al., 2010). Nowadays, one of the major concerns in modeling is the elaboration of indexes that evaluate the accuracy (RRMSE) of the estimates (Li and Heap, 2008).

The isolated interpretation of the cross-validation parameters ( $a$ and $b$ ) prevents the researcher from quantitatively comparing the quality of the predictions obtained for different attributes. This may generate misinterpretations about the real boundaries of the field variability classes. Such mistake occurs because of the different amplitudes (maximum and minimum values) and values of the variation coefficient of the studied attributes. The RRMSE index use, 
Table 1

Parameters of the adjusted variogram models.

\begin{tabular}{|c|c|c|c|c|c|c|c|c|c|}
\hline \multirow[t]{2}{*}{ Attributes } & \multirow[t]{2}{*}{ Model } & \multirow[t]{2}{*}{$\mathrm{C}_{0}$} & \multirow[t]{2}{*}{$\mathrm{C}_{0}+\mathrm{C}_{1}$} & \multirow[t]{2}{*}{$\operatorname{SDD}(\%)$} & \multirow[t]{2}{*}{ Range (m) } & \multirow[t]{2}{*}{$\mathrm{R}^{2}$} & \multicolumn{3}{|c|}{ Cross-validation } \\
\hline & & & & & & & $\mathrm{a}$ & $\mathrm{b}$ & RRMSE (\%) \\
\hline \multicolumn{10}{|l|}{$0.00-0.25$} \\
\hline Clay & Spherical & 14.2 & 86.2 & 16.0 & 930.0 & 1.0 & 0.0 & 1.1 & 14.2 \\
\hline Silt & Exponential & 9.4 & 32.1 & 29.0 & 1290.5 & 1.0 & 0.0 & 1.1 & 19.8 \\
\hline TS & Exponential & 18.1 & 156.0 & 12.0 & 1155.1 & 0.9 & 0.2 & 1.2 & 4.7 \\
\hline $\mathrm{OM}$ & Spherical & 0.2 & 0.4 & 43.0 & 1410.8 & 0.9 & -0.1 & 1.0 & 0.2 \\
\hline $\mathrm{pH}$ & Spherical & 0.1 & 0.2 & 28.0 & 255.6 & 0.8 & 0.0 & 1.0 & 0.1 \\
\hline $\mathrm{P}_{\text {avail. }}$ & Spherical & 0.2 & 0.3 & 67.0 & 548.3 & 0.7 & 8.1 & 0.8 & 0.6 \\
\hline $\mathrm{H}+\mathrm{Al}$ & Gaussian & 0.6 & 1.6 & 39.0 & 1300.7 & 0.9 & 0.1 & 1.0 & 0.3 \\
\hline SB & Spherical & 0.8 & 4.5 & 17.0 & 444.0 & 1.0 & 0.2 & 1.0 & 0.4 \\
\hline CEC & Exponential & 0.3 & 4.7 & 7.0 & 1080.1 & 1.0 & -0.1 & 1.0 & 0.2 \\
\hline V\% & Exponential & 38.2 & 218.1 & 18.0 & 437.3 & 0.9 & -0.1 & 1.0 & 0.3 \\
\hline MS & Spherical & $95.510^{3}$ & $110810^{3}$ & 9.0 & 1033.1 & 1.0 & 1.2 & 1.1 & 11.9 \\
\hline Hue & Spherical & 0.0 & 0.1 & 29.0 & 383.8 & 0.9 & 0.0 & 1.0 & 0.0 \\
\hline Value & Spherical & 0.0 & 0.1 & 40.0 & 376.4 & 0.8 & 0.1 & 1.0 & 0.1 \\
\hline Chroma & Spherical & 0.0 & 0.1 & 20.0 & 587.0 & 1.0 & 0.2 & 1.0 & 0.0 \\
\hline \multicolumn{10}{|l|}{$0.25-0.50$} \\
\hline Clay & Spherical & 14.1 & 78.3 & 18.0 & 746.7 & 1.0 & 0.0 & 1.1 & 6.2 \\
\hline Silt & Spherical & 6.9 & 29.1 & 24.0 & 622.9 & 1.0 & 0.1 & 1.0 & 2.4 \\
\hline TS & Spherical & 28.5 & 158.5 & 18.0 & 792.2 & 1.0 & -0.1 & 1.1 & 4.4 \\
\hline $\mathrm{OM}$ & Spherical & 0.2 & 0.3 & 57.0 & 1267.2 & 0.9 & 0.1 & 1.0 & 0.2 \\
\hline $\mathrm{pH}$ & Spherical & 0.0 & 0.0 & 0.0 & 381.6 & 0.8 & 2.0 & 0.6 & 0.1 \\
\hline $\mathrm{P}_{\text {avail. }}$ & Exponential & 0.2 & 0.4 & 54.0 & 574.2 & 0.9 & 0.6 & 1.0 & 0.9 \\
\hline $\mathrm{H}+\mathrm{Al}$ & Gaussian & 0.6 & 1.1 & 55.0 & 1597.0 & 0.8 & 0.5 & 0.9 & 0.3 \\
\hline SB & Spherical & 0.1 & 0.2 & 37.0 & 572.7 & 0.8 & 0.1 & 1.0 & 0.4 \\
\hline CEC & Spherical & 0.9 & 3.1 & 29.0 & 818.6 & 0.9 & 0.0 & 1.0 & 0.2 \\
\hline $\mathrm{V} \%$ & Spherical & 113.6 & 188.0 & 60.0 & 469.2 & 0.9 & 4.8 & 0.9 & 0.3 \\
\hline MS & Spherical & $77.1410^{3}$ & $113610^{3}$ & 7.0 & 1027.3 & 1.0 & 6.0 & 1.1 & 4.4 \\
\hline \multicolumn{10}{|l|}{ Plant } \\
\hline NDVI 2011 & Spherical & 0.0 & 0.0 & 39.0 & 1486.0 & 1.0 & 0.5 & 0.3 & 0.1 \\
\hline NDVI 2010 & Exponential & 0.0 & 0.0 & 48.0 & 1698.0 & 0.8 & 0.3 & 0.2 & 0.1 \\
\hline NDVI 2009 & Exponential & 0.0 & 0.0 & 48.0 & 1317.0 & 0.8 & 0.3 & 0.4 & 0.1 \\
\hline
\end{tabular}

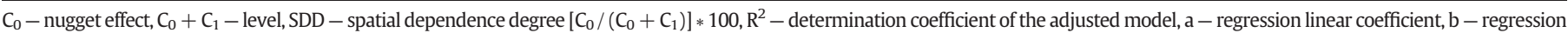

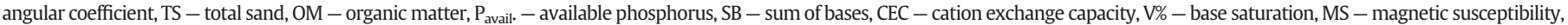
NDVI - Normalized Difference Vegetation Index.

apart from reducing this kind of mistake, promotes the quantitative comparison of the prediction accuracy among the different attributes. In this way, the decision making based on the variability maps becomes more reliable (Li and Heap, 2008).

The RRMSE can be interpreted as an index of accuracy, and allows comparisons to be standardized between different attributes. This feature is important because the researcher can choose the attribute with more accurate to represent the variability of an area. The MS shows a similar RRMSE (6.22-11.85\%) to the clay content one (6.22-14.16\%). Regarding the other indirect measurements, such as the electrical conductivity (RRMSE ranging from 34.61 to $42.69 \%$ ) (Li et al., 2007), the MS showed the best performances. This occurs because the electrical conductivity was originally developed for temperate regions with low contents of iron oxides. Some authors (Wu et al., 2008) report that this technique may undergo some amendments in regions with high iron oxide concentrations. Research results show that the measurement of the electrical conductivity with a contact sensor presents better performance in Dystroferric Red Oxisols with lower clay content (Machado et al., 2006). This information is important for future studies to delineate areas with different amounts of iron oxides in the soil as well as the total iron content $\left(\mathrm{Fe}_{2} \mathrm{O}_{3}\right)$, helping the researcher to choose the most suitable analysis tool for the indirect study of the variability of attributes soil.

The RRMSE values for the clay content ( 14.16 and $6.22 \%$ for the 0.00 $0.25 \mathrm{~m}$ and $0.25-0.50 \mathrm{~m}$ depths, respectively), $\mathrm{pH}$ ( $0.07 \%$ for both depths), $\mathrm{OM}(0.16$ and $0.17 \%$ for the $0.00-0.25 \mathrm{~m}$ and $0.25-0.50 \mathrm{~m}$ depths, respectively) and $P_{\text {avail }}$ ( 0.55 and $0.94 \%$ for the $0.00-0.25 \mathrm{~m}$ and $0.25-0.50 \mathrm{~m}$ depths, respectively) corroborate the literature ones. Schloeder et al. (2001), when working in an area of 140,000 ha with 43 points, obtained the RRMSE values of $5.12 \%$ for clay content, $3.62 \%$ for $\mathrm{pH}, 102.16 \%$ for
$\mathrm{P}_{\text {avail }}$. and 6.39\% for OM. Voltz and Webster (1990), when studying an area of 3.2 ha with 107 points, reached a RRMSE value of $23.25 \%$ for clay content. Brus et al. (1996) reached a RRMSE of $61.72 \%$ for $\mathrm{P}_{\text {avail. }}$ in an area of 4800 ha that was modeled with 188 points.

The integration of the spatial variability maps and the most representative peaks from the SMW analysis (Fig. 6) is shown in Fig. 7. Such integration clarified which variability class was most representative of the detailed mapping unit, what is also called of specific management area (Sanchez et al., 2012b; Siqueira et al., 2010a). Minasny and McBratney (2007) and Trangmar et al. (1985) highlight the importance of the spatial distribution of the soil attributes for the boundary identification among taxonomic classes.

When the spatial variability maps (Fig. 7) are compared with the soil map (Fig. 1e), it is verified that the superior part of the landscape presents a variation in the clay content of $380-740 \mathrm{~g} \mathrm{~kg}-1(0.00-$ $0.25 \mathrm{~m}$ ) and $440-640 \mathrm{~g} \mathrm{~kg}^{-1}(0.25-0.50 \mathrm{~m})$. According to the soil map of the area (scale of 1:12,000, which is considered detailed), the top soils belong to the clayey class $\left(350 \leq\right.$ clay content $<600 \mathrm{~g} \mathrm{~kg}^{-1}$ ) while the subsoils belong to the medium texture class (150 $\leq$ clay content $<350 \mathrm{~g} \mathrm{~kg}^{-1}$ ). The soil map of the area, therefore, does not properly represent the field variability classes. This occurs because the conceptual boundaries, which were created to comprise the taxon different soils, are not representative of the variability classes of the attributes throughout the landscape, so that the taxonomic unit does not correspond to the mapping unit.

The same occurs with the technical map of the production (Fig. 1f) which best environments are located in the landscape superior part (environments A and B), while the worst ones are in the inferior ( $\mathrm{C}$ and D). The crop spatial variability, which is represented by the NDVI maps, is more associated with the variability classes than with the 
recommended production environments. Johnson and Richard (2005), when studying the detailed characterization of the spatial variability of soil and sugarcane attributes in two locations along three years, reported a high spatial correlation among soil and plant attributes.

It is observed that the isolines of the variability classes are parallel to the East-west axis, while in the production environment map (Fig. 1f), the direction is North-south, following the soil map boundaries. In tropical environments, the real soil variability was disguised by less detailed recognition surveys. This kind of environment promoted a false sense of uniformity, what contributed to broaden the distance among researchers that interpreted the maps and farmers that wanted to better know the soil that they cultivated (Buol, 1990). Results of the global pedodiversity and taxonomic distance elaboration based on climatic zones (Minasny et al., 2010) indicate that our study area holds the smallest taxonomic distance $(0.44)$. This denotes the need for more details of these locations in order to better understand the field variability.

When the spatial variability maps are compared with the map of geomorphometric compartments (Fig. 1g), it is noted that the isolines of the variability classes did not show any similarity with the geomorphometric boundaries. The method suggested by Vasconcelos et al. (2012) may be considered an upgrade both in the conceptual sense of a three-dimensional approach of the landscape and convenience for the characterization of large areas without the subjectivity of compartment nomination. However, method was not effective for the understanding of the variability classes presented in the studied region, where the parental material had more weight than relief. Based on other studies on the variability of different soil attributes and landscape conceptual models (Barbieri et al., 2009; Camargo et al., 2010, 2013; Martins Filho et al., 2009; Sanchez et al., 2009, 2012a, 2012b), the model described by Vasconcelos et al. (2012) possibly presents great potential to be used in locations under the Sandstone, Bauru Group, Adamantina Formation, where the relief is the most relevant factor. In these areas, a great part of the variability classes of the soil attributes is subjected to the landscape forms, which are conceptually characterized by the model described by Troeh (1965). These findings may help future studies to understand the behave of the geomorphometric signature in different geologic region and which curvature of images have more influence in the soil data. For landscapes formed on sedimentary rocks such as sandstones of Bauru Group, the plan curvatures may have better results. In regions on basalt rocks and basalt transitions, as in this study, where models Dalrymple et al. (1968) and Daniels et al. (1971) showed better results, the profile of curvature may be more useful in detailed segmentation of relief.

We highlight the resemblance of the MS spatial continuity with the other attributes for both depths, where the isolines are parallel to the East-west axis. Siqueira et al. (2010b), when studying pedotransference functions with MS, found good correlations for the clay content $(0.68)$, base saturation $(-0.69)$ and hematite content $(0.81)$. The same authors concluded that the MS may help at the variability characterization of the soil attributes in large areas. The minerals with magnetic capacity store natural archives that contain records of the soil processes and formation (Maher and Thompson, 1999). Thus, it may be considered a pedoindicator for different areas or mapping units. The higher MS values in the upper part of the landscape may be more related to litogenic magnetite presence. In the central and lower part of the landscape lower values MS may be more related ferrimagnetic ferrihydrite and maghemite of pedogenic.

Fig. 8 shows the boundaries among the outlined mapping units based on the spatial variability classes corroborated by the most representative SMW peaks (2nd to 5th peaks) and field conceptual boundaries. In this work we call mapping unit areas whose pattern of variability of soil attributes is known (amplitude and direction of the contours of the levels of the attributes).

Delden et al. (2011) report that the mapping scale must be establish according to the utilization and convenience for the final user. For this reason, even when there are subdivisions to be considered, as indicated by peaks 1 st, 3rd and 4 th (Fig. 6), we believe that the proposed design better meets the needs of the São Paulo State sugarcane industry because of two reasons. The first is the management facility of the information required in larger amounts. In this way, the planning of the agricultural practices (planting, fertilizing, harvesting, etc.), when the three proposed mapping units are considered, may be more practical and profitable than the planning based on the production environment map (Fig. 1f). As shown by the contours of the map variability of NDVI for different years came with the direction of the isoline maps of soil attributes and does not corroborate the map production environments. Campos et al. (2008) and Sanchez et al. (2012a), when studying an area of 505 and 200 ha, respectively, both cultivated with sugarcane, demonstrated that this kind of design may be used in the agricultural sector with great benefits, such as the sustainable planning.

The second reason is related to the agricultural automation and dimensioning of the sugarcane planting areas. The strategy is to increase the size of the management units to improve the operation of mechanized harvesting of sugarcane. Nowadays, the smallest organizational agricultural unit in the São Paulo State sugarcane industry is the plot. It is expected that, within the same plot, the variability is minimum, what, most of the times, does not occur, as shown in the comparison of map production environment (Fig. 1f) with maps of variability of soil attributes (Fig. 7). The plot redesign, based on the variability, may enhance the operational capacity, because the field can be extended in the direction of minimum variation, promoting more efficiency of the machinery maneuver and usage time. The maneuverability is considered one of the most important factors on the performance evaluation of agricultural machinery (Hunt, 1995; Mialhe, 1974).

The boundaries (mean \pm standard deviation) of the designed polygons based on the field variability are shown in Table 2. It is observed that the designed areas with higher MS values (I and II) also presented higher values of TCH, TRS and NDVI 2010. Marques et al. (2014), when working with Haplustalf close to the Sandstone, Bauru Group, found a correlation of $-0.28(\mathrm{P}<0.01)$ between the MS and Brix sugarcane, $-0.26(\mathrm{P}<0.01)$ between the MS and Pol (percentage of apparent sucrose in a solution), and $0.35(\mathrm{P}<0.01)$ between the NIR spectrum and yield sugarcane.

According to the Brazilian Soil Classification System (Embrapa, 2006), the polygon I fits in the mesoferric class $\left(\mathrm{Fe}_{2} \mathrm{O}_{3}\right.$ contents ranging from 80 to $180 \mathrm{~g} \mathrm{~kg}^{-1}$ ), while the polygons II and III are suited for the hypoferric class $\left(\mathrm{Fe}_{2} \mathrm{O}_{3}\right.$ contents of $\left.<80 \mathrm{~g} \mathrm{~kg}^{-1}\right)$. Although the ratio among $\mathrm{Fe}_{2} \mathrm{O}_{3}$ and the polygons II and III is 1.2, the MS ratio is 3.1. The MS current sensors were sensitive even in regions with low variation $\mathrm{Fe}_{2} \mathrm{O}_{3}$ in soil. As important as the presence of iron is the balance between oxidized iron (III) and reduced (II) in the crystal structure. These forms of iron are related to higher or lower magnetic expression in soils. The isomorphic substitution of iron by aluminum or titanium in the crystal structure also influence the magnetic behavior of minerals (Michel et al., 2010; Torrent et al., 2006, 2010).

The MS, therefore, may be considered an interesting attribute to assist at the delimitation of areas that show different agricultural potential, such as P adsorption (Camargo et al., 2014), $\mathrm{CO}_{2}$ emission (Barrios et al., 2012), quantitative and qualitative characteristics of crop production (Cortez et al., 2011) and erosion (Santos et al., 2013). The MS values found for both depths (4962 and $399610^{-8} \mathrm{~m}^{3} \mathrm{~kg}^{-1}$, respectively) are close to those values detected in diagnostic horizons of Oxisols (5772 $10^{-8} \mathrm{~m}^{3} \mathrm{~kg}^{-1}$ ) from Basalt (Costa et al., 1999).

Berquó et al. (2004), when studying the MS in areas under an Alluvial Deposit, did not observe great variations in its values up to the 4-5 m depth. Also, Ghidin et al. (2006), when working with Oxisols originated from basaltic rocks, did not find variations in the clay content between the surface and diagnostic horizons. The same was noted for $\mathrm{Fe}_{2} \mathrm{O}_{3}$ and MCD Hm 110, especially in ferric soils $\left(\mathrm{Fe}_{2} \mathrm{O}_{3}\right.$ contents ranging from $180 \mathrm{~g} \mathrm{~kg}^{-1}$ to $360 \mathrm{~g} \mathrm{~kg}^{-1}$ ). Other authors (Matias et al., 2013) report that the MS spatial variability, at $0.00-0.20 \mathrm{~m}$ and 

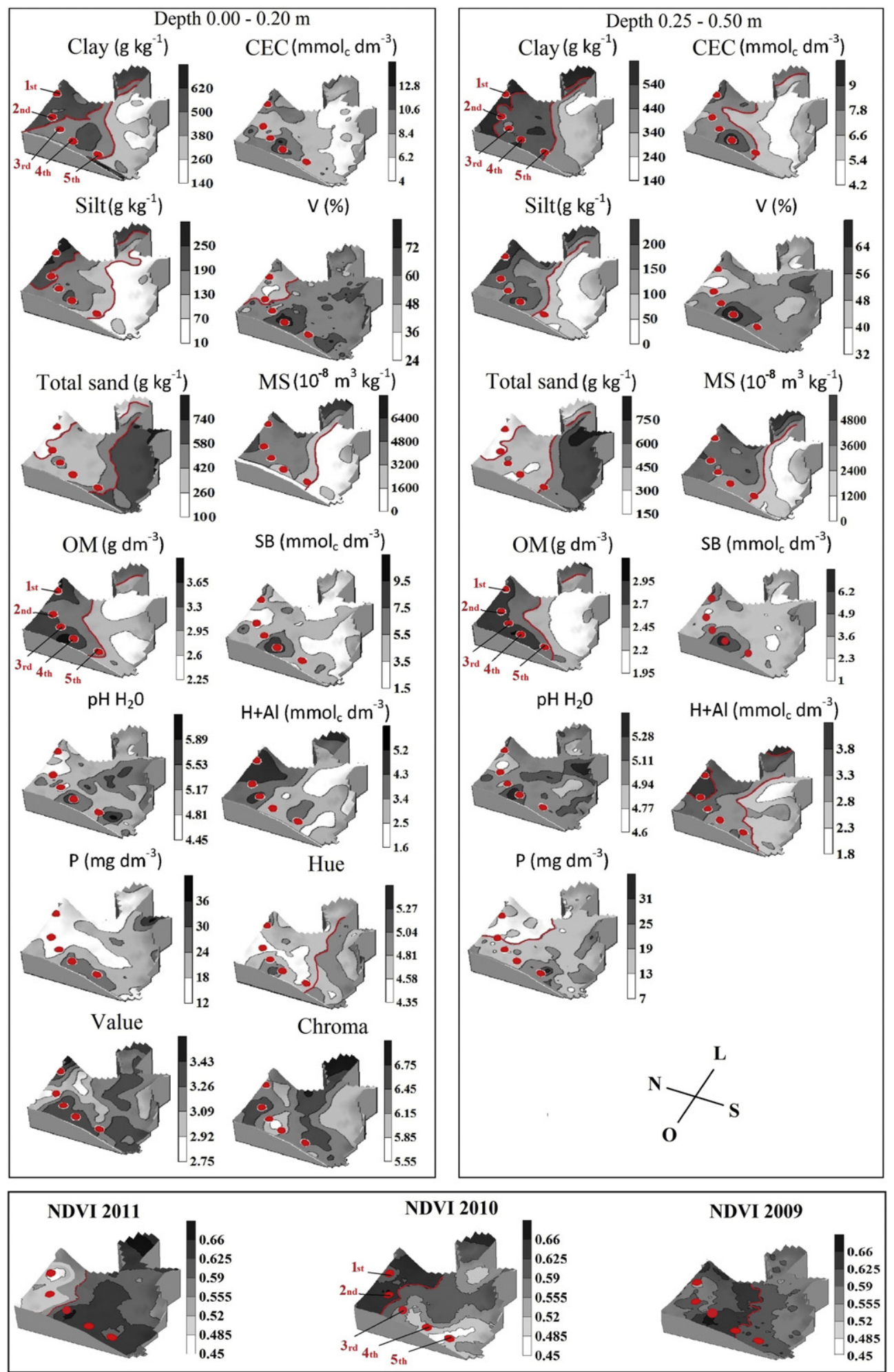

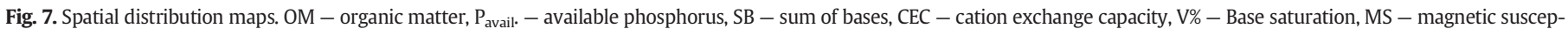

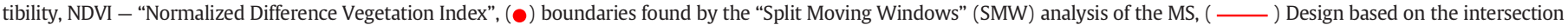
among the SMW boundaries and variability map isolines, (1st, 2nd, 3rd, 4th, 5th) Most representative SMW peaks.

0.60-0.80 m depths, was similar in an area of 770 ha. Based on the low vertical variability of the presented results (Berquó et al., 2004; Costa et al., 1999; Ghidin et al., 2006), particularly the MS ones, we can infer that the values shown in Table 2, demonstrate, to some extent, the representativeness of pedological horizons. In this regard, Resende et al. (1988b) suggest the MS use as a criterion for soil classification due to its determination simplicity.
Increased tint (calculated ERD) drive mapping I (YR 4.62) for the mapping unit III (YR 4.84) indicating color change red to yellow along the transect. Comparing the results of hue in Table 2 for the three mapping units delineated in the soil map (Fig. 1e), it is noticed that the hue information, as calculated by the ERD may be useful for readjustment of limits in soil maps prepared based on information from the Munsell color chart. Studying measures of soil color with the Munsell color chart and 


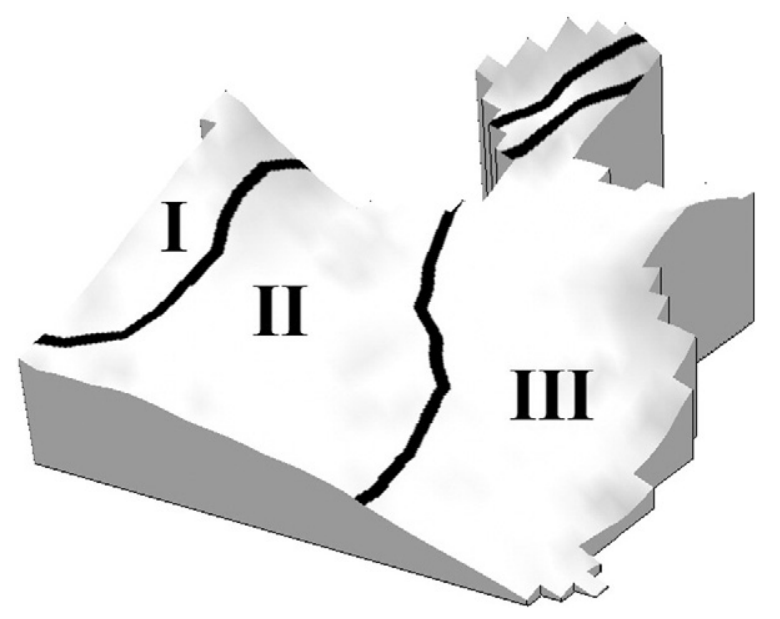

Fig. 8. Proposed design of the detailed mapping units based on the validation of the conceptual models for the soil-landscape relation, using the "Split Moving Windows", Geostatistics and magnetic susceptibility.

colorimetry, Botelho et al. (2006) found the same hue value in the Munsell color chart (10YR) and variations in hue when used colorimetry (8.20 YR, 8.46 YR, 7.84 YR, 7.72 YR). As presented to them by hue values found in the Munsell color chart for deviations of more accurate techniques.

Increasing the ratio $\mathrm{Kt} /(\mathrm{Kt}+\mathrm{Gb})$ of the mapping unit I (0.77) for mapping unit III (0.82) indicates that the kaolinite content in the soil decreases from the top to the foot of deposition. There was also increase the DMC for both $\mathrm{Hm}$ and for Gt unit I to unit III. By presenting different conditions of redox, unit III, provides a better environment for the crystallization of iron oxides. Cunha et al. (2005) and Camargo et al. (2008a) also observed the same behavior for the DMC Hm and Gt. On the highest levels of kaolinite found in unit III contrasting with lower levels of total iron content (44.4 $\mathrm{g} \mathrm{kg}^{-1}$ ). Plaçon and Tchoubar (1977) and Mestdagh et al. (1980) report that the pedogenetic environment preferred kaolinite is the one with lower iron content. The replacement of aluminum by iron in octahedral positions can cause structural disorganization of kaolinite. The rocks rich in iron are originally low in silica. Furthermore the free iron oxides would absorb little silica present in the environment not allowing or reducing its ability to combine with aluminum to form kaolinite (Mestdagh et al., 1980). The results show that mineralogical mapping units are delineated in three distinct pedogenic environments, and that the culture of cane sugar responds to these units according to the results of NDVI, 2009, 2010 and 2011.

The results indicate that soil color determined by Diffuse Reflectance Spectroscopy, and especially MS, identify mapping units that correspond to the boundaries between the environments of generation of the major minerals pedogeneticals from the tropical region (hematite, goethite, maghemite, ferrihydrite, kaolinite and gibbsite). The use of alternative methods for identification and quantification of iron oxides (Bahia et al., 2015) associated with characterization tools of spatial variability in upscaling and downscale may improve understanding of soil formation processes continuously across the landscape. Thus, it will be possible to develop models of local and regional pedogeomorphological evolution (Vasconcelos et al., 2013) and use SM as a landscape evolution rate. In the study of Vasconcelos et al. (2013) MS was sensitive to the hydromorphization process which influences the dynamics of redox iron and therefore in the new formation and crystallinity of minerals with different magnetic expressions such as ferrimagnetic ferrihydrite and maghemite (Michel et al., 2010; Resende et al., 1988a, 1988b; Torrent et al., 2006, 2010) and vary with the conditions of formation of other minerals such as kaolinite and gibbsite.

\section{Conclusion}

Magnetic susceptibility (MS) was more efficient in the compartmentalization of the landscape (identification of areas with different patterns of pedogenetic variability) than the hue determined by diffuse reflectance spectroscopy for Oxisols under the transition Basalt and Colluvial-Elluvial-Alluvial Deposits.

The MS and soil-landscape relationship were effective in delineating units of detailed mapping. Due to the lack of protocols for identifying areas based on their pattern of variability, the results of this study can serve as an alternative strategy for mapping of soil attributes and identification of areas with different patterns of pedogenetic variability based on the analysis of the transect and its relationship with the landscape.

\section{Acknowledgments}

To São Paulo Research Foundation (FAPESP) for granting a graduate scholarship to the first author (Project number 2011/06053-3) $<$ http://www.bv.fapesp.br/pt/bolsas/126039/suscetibilidade-magneticae-espectroscopia-de-reflectancia-disfusa-na-identificacao-de-areas-demane/> and Brazilian National Council for Scientific and Technological Development - CNPq.

Table 2

Physical, chemical and mineralogical characterization and crop response in the designed polygons based on the field variability.

\begin{tabular}{|c|c|c|c|c|}
\hline \multirow[t]{2}{*}{ Attributes } & \multirow[t]{2}{*}{ Statistics } & \multicolumn{3}{|c|}{ Designed polygons } \\
\hline & & I & II & III \\
\hline \multicolumn{5}{|l|}{$0.00-0.25 \mathrm{~m}$} \\
\hline \multirow[t]{2}{*}{ MS $\left(10^{-8} \mathrm{~m}^{3} \mathrm{~kg}^{-1}\right)$} & Mean & $4962.00 \mathrm{a}$ & $3996.00 \mathrm{~b}$ & $1273.00 \mathrm{c}$ \\
\hline & SD & 993.00 & 979.00 & 1009.00 \\
\hline \multirow{2}{*}{ Clay content $\left(\mathrm{g} \mathrm{kg}^{-1}\right)$} & Mean & $52.90 \mathrm{a}$ & 49.66a & 29.02b \\
\hline & SD & 10.35 & 6.12 & 9.89 \\
\hline \multirow[t]{2}{*}{ Hue (YR) } & Mean & $4.62 \mathrm{~b}$ & $4.65 b$ & $4.84 a$ \\
\hline & SD & 0.30 & 0.22 & 0.28 \\
\hline \multirow[t]{2}{*}{ MCD Gt110 (nm) } & Mean & $18.24 \mathrm{a}$ & $29.70 a$ & $34.39 a$ \\
\hline & SD & 2.35 & 16.13 & 17.47 \\
\hline \multirow[t]{2}{*}{ MCD Hm110 (nm) } & Mean & $27.19 \mathrm{c}$ & $38.23 b$ & $49.99 a$ \\
\hline & SD & 3.93 & 5.90 & 9.47 \\
\hline \multirow[t]{2}{*}{ MCD Hm012 (nm) } & Mean & $57.36 \mathrm{bc}$ & 68.07ab & $82.77 a$ \\
\hline & SD & 7.32 & 15.63 & 22.83 \\
\hline \multirow[t]{2}{*}{ Ratio Gt/(Gt + Hm) } & Mean & $0.33 a$ & $0.30 \mathrm{a}$ & $0.30 \mathrm{a}$ \\
\hline & SD & 0.03 & 0.09 & 0.05 \\
\hline \multirow{2}{*}{$\mathrm{Fe}_{2} \mathrm{O}_{3}\left(\mathrm{~g} \mathrm{~kg}^{-1}\right)$} & Mean & 129.09a & $55.37 \mathrm{~b}$ & $44.46 b$ \\
\hline & SD & 70.58 & 15.30 & 35.89 \\
\hline \multirow[t]{2}{*}{ Ratio $\mathrm{Kt} /(\mathrm{Kt}+\mathrm{Gb})$} & Mean & $0.77 \mathrm{bc}$ & $0.81 \mathrm{ab}$ & $0.82 \mathrm{a}$ \\
\hline & SD & 0.01 & 0.04 & 0.02 \\
\hline \multicolumn{5}{|l|}{$0.25-0.50 \mathrm{~m}$} \\
\hline \multirow[t]{2}{*}{$\operatorname{MS}\left(10^{-8} \mathrm{~m}^{3} \mathrm{~kg}^{-1}\right)$} & Mean & $5059.00 \mathrm{a}$ & $4115.00 \mathrm{~b}$ & $1307.00 \mathrm{c}$ \\
\hline & SD & 1320.00 & 990.00 & 978.00 \\
\hline \multirow{2}{*}{ Clay content $\left(\mathrm{g} \mathrm{kg}^{-1}\right)$} & Mean & $57.15 a$ & $52.61 b$ & $30.47 c$ \\
\hline & SD & 5.04 & 5.51 & 10.34 \\
\hline \multicolumn{5}{|l|}{ Plant } \\
\hline \multirow[t]{2}{*}{ NDVI 2011} & Mean & $0.51 \mathrm{c}$ & $0.53 b$ & $0.56 a$ \\
\hline & SD & 0.05 & 0.06 & 0.05 \\
\hline \multirow[t]{2}{*}{ NDVI 2010} & Mean & $0.60 \mathrm{a}$ & $0.57 b$ & $0.54 \mathrm{c}$ \\
\hline & SD & 0.03 & 0.05 & 0.04 \\
\hline \multirow[t]{2}{*}{ NDVI 2009} & Mean & $0.58 \mathrm{~b}$ & $0.61 \mathrm{a}$ & $0.58 \mathrm{a}$ \\
\hline & SD & 0.06 & 0.04 & 0.04 \\
\hline $\mathrm{TCH}$ & Mean & 85.22 & 85.98 & 78.71 \\
\hline TRS & Mean & 92.85 & 90.34 & 85.91 \\
\hline
\end{tabular}

TCH - ton of culms ha ${ }^{-1}$, TRS - total reducing sugars, MS - magnetic susceptibility Fed - Iron dithionite, Feo - Iron oxalate, Hm - Hematite, Gt - Goethite, Kt - Kaolinite, Gb - Gibbsite, MCD - mean crystal diameter, NDVI - "Normalized Difference Vegetation Index"; MS, Clay content, Hue - 150 samples; Ratio, $\mathrm{MCD}, \mathrm{Fe}_{2} \mathrm{O}_{3}-16$ samples; NDVI - 70 samples; TCH, TRS -3 samples (polygon I composed of 6 representative subsamples of 31.50 ha; polygon II composed of 13 representative subsamples of 76.98 ha; and polygon III composed of 13 representative subsamples of $185.05 \mathrm{ha}$ ). Means followed by the same letter do not differ from each other by the Tukey's test at $5 \%$ of probability. 


\section{References}

Bahia, A.S.R.S., Jr, Marques, Siqueira, D.S., 2015. Procedures using diffuse reflectance spectroscopy for estimating hematite and goethite in Oxisols of São Paulo, Brazil. Geoderma Reg. 5, 150-156.

Barbieri, D.M., Marques Jr., J., Alleoni, L.R.F., Garbuio, F.J., Camargo, L.A., 2009. Hillslope curvature, clay mineralogy, and phosphorus adsorption in an Alfisol cultivated with sugarcane. Sci. Agrícola 66, 819-826.

Barrios, M.R., Marques Jr., J., Panosso, A.R., Siqueira, D.S., Scala Jr., N.L., 2012. Magnetic susceptibility to identify landscape segment on a detailed scale in the region of Jaboticabal, São Paulo, Brazil. Rev. Bras. Ciênc. Solo 36, 1073-1082.

Barrón, V., Mello, J.W.V., Torrent, J., 2000. Caracterização de óxidos de ferro em solos por Espectroscopia de Reflectância Difusa, in: Novais, R.F., Alvarez V., V.H., Schaefer, C.E.G.R. (Eds.), Tópicos em ciência do solo. E-Publishing Inc.,Viçosa, Sociedade Brasileira de Ciência do Solo, pp.139-162 (in Portuguese).

Bartington, 2013. Operation Manual for MS2 Magnetic Susceptibility System Available in: http://www.bartington.com/Literaturepdf/Operation\%20Manuals/om0408\%20MS2.pd (Accessed at: 24/01/2013).

Bazaglia Filho, O., Rizzo, R., Lepsch, I.F., Prado, H., Gomes, F.H., Mazza, J.A., Demattê, J.A.M., 2013. Comparison between detailed digital and conventional soil maps of an area with complex geology. Rev. Bras. Ciênc. Solo 37, 1136-1148.

Berg, M.V.D., Lepsch, I.F., Sakai, E., 1987. Solos de planícies aluviais do vale do Rio Ribeira de Iguape, SP. I-Padrões de distribuição. Rev. Bras. Ciênc. Solo 11, 315-321 (in Portuguese).

Berquó, T.S., Thompson, R., Partiti, C.S.M., 2004. Magnetic study of Brazilian peats from São Paulo state. Geoderma 118, 233-243.

Botelho, Márcio Ramos, et al., 2006. Medida da cor em solos do Rio Grande do Su com a carta de Munsell e por colorimetria. Ciênc. Rural 36, 1179-1185 (in Portuguese).

Boughton, E.A., Quintana-Ascencio, A., Menges, E.S., Boughton, R.K., 2006. Association of ecotones with relative elevation and fire in an upland Florida landscape. J. Veg. Sci. 17, 361-368.

Brasil, 1960. Ministério da Agricultura. Centro Nacional de Ensino e Pesquisas Agronômicas. Serviço Nacional de Pesquisas Agronômicas. Comissão de Solos. Levantamento de reconhecimento dos solos do Estado de São Paulo: contribuição à carta de solos do Brasil. Rio de Janeiro (634 pp. (Brasil. Ministerio da Agricultura. SNPA. Boletim, 12). (in Portuguese))

Brasil, 2012. Empresa de Pesquisa Energética. Balanço Energético Nacional 2012 - Ano base 2011: Resultados Preliminares Rio de Janeiro: EPE 51 pp.: 18 il. Available in: http://www.lepten.ufsc.br/disciplinas/emc5489/arquivos/pdf/textos/2012 Resultados_Pre_BEN_2012.pdf (Accessed at: 18 de jan. 2013. (in Portuguese)).

Brasil. Ministério das Minas e Energia, Secretaria Geral, 1981. PROJETO RADAM BRASIL: Geologia, geomorfologia, pedologia, vegetação e uso potencial da terra. Rio de Janeiro (in Portuguese).

Brus, D.J., Gruijter, J.J., Marsman, B.A., Visschers, R., Bregt, A.K., Breeuwsma, A Bouma, J., 1996. The performance of spatial interpolation methods and choropleth maps to estimate properties at points: a soil survey case study. Environmetrics 7, 1-16.

Buol, S.W., 1990. Suelos tropicales: classificación y características. In: Salinas, J.G., Gouley, L.M. (Eds.), Sorgo para suelos ácidos. CIAT, Cali, pp. 49-62 (in Spanish).

Camargo, L.A., Marques Jr., J., Pereira, G.T., Horvat, R.A., 2008a. Variabilidade espacial de atributos mineralógicos de um Latossolo sob diferentes formas de relevo.I-Mineralogia da fração argila. Rev. Bras. Ciênc. Solo 32, 2269-2277 (in Portuguese).

Camargo, L.A., Marques Jr., J., Pereira, G.T., Horvat, R.A., 2008b. Variabilidade espacial de atributos mineralógicos de um latossolo sob diferentes formas do relevo: II - correlação espacial entre mineralogia e agregados. Rev. Bras. Ciênc. Solo 32, 2279-2288 (in Portuguese)

Camargo, L.A., Marques Jr., J., Pereira, G.T., 2010. Spatial variability of physical attributes of an Alfisol under different hillslope curvatures. Rev. Bras. Ciênc. Solo 34,617-630.

Camargo, L.A., Marques Jr., J., Pereira, G.T., Alleoni, L.R.F., 2013. Spatial correlation between the composition of the clay fraction and contents of available phosphorus of an Oxiso at hillslope scale. Catena 100, 100-106.

Camargo, L.A., Marques Jr., J., Pereira, G.P., Bahia, A.S.R.S., 2014. Clay mineralogy and magnetic susceptibility of Oxisols in geomorphic surfaces. Sci. Agric. 71, 244-256.

Cambardella, C.A., Moorman, T.B., Novak, J.M., Parkin, T.B., Karlen, D.L., Turco, R.F., Konopka, A.E., 1994. Field-scale variability of soil properties in central Iowa soils. Soil Sci. Soc. Am. J. 58, 1501-1511.

Campos, M.C.C., Marques Júnior, J., Pereira, G.T., Souza, Z.M., 2008. Barbieri, D.M.,2008 Aplicação de adubo e corretivo após o corte da cana-planta utilizando técnicas geoestatísticas. Ciênc. Rural 38, 974-980 (in Portuguese).

Chander, G., Markham, B., 2003. Revised Landsat-5 TM Radiometric Calibration Procedures and Post calibration Dynamic Ranges. IEEE Trans. Geosci. Remote Sens. 4 (2.764-2.677).

Choesin, D.N., 2001. Use of landscape ecological analysis to determine ecotone locations: an evaluation based on field data. J. Mt. Sci. 6, 91-99.

Consecana, 2003. Council of Producers of Sugar Cane, Sugar and Alcohol in the State of São Paulo. Directions Manual. Piracicaba (118 pp. (in Portuguese)).

Cortez, L.A., Marques Jr., J., Peluco, R.G., Teixeira, D.B.T., Siqueira, D.S., 2011 Suscetibilidade magnética para identificação de áreas de manejo específico em citricultura. Energ. Agric. 26, 60-79 (in Portuguese).

Costa, A.C.S., Bigham, J.B., Rhoton, F.E., Traina, S.J., 1999. Quantification and characterization of maghemite in soils derived from volcanic rocks in southern Brazil. Clay Clay Miner 4, 466-473.

Cunha, P., Marques Jr., J., Curi, N., Pereira, G.T., Lepsch, I.F., 2005. Geomorphic surfaces and attributes of Oxisols in a sequence of sandstone-Basalt Jaboticabal (SP). Rev. Bras. Ciênc. Solo 29, 81-90 (in Portuguese).
Curi, N., 1983. Lithosequence and Toposequence of Oxisols from Goiás and Minas Gerais, Brazil. 1983158 f. Tesis (Ph.D.) Purdue University, West Lafayette.

Dalrymple, J.B., Blong, R.J., Conacher, A.J., 1968. A hypothetical nine unit land a surface model. Z. Geomorphol. 12, 60-76.

Daniels, R.B., Hammer, R.D., 1992. Soil Geomorphology. John Wiley \& Sons, New York (236 pp.)

Daniels, R.B., Gamble, E.F., Cady, J.G., 1971. The relation between geomorphology and soil morphology and genesis. Adv. Agron. 23, 51-87.

Dearing, J.A., 1994. Environmental Magnetic Susceptibility. Using the Bartington MS2 System. British Library, England (104 pp.)

Delarmelinda, E.A., Wadt, P.G.S., Anjos, L.H.C., Masutti, C.S.M., Silva, E.F., Silva, M.B. Coelho, R.M., Shimizu, S.H., Couto, W.H., 2011. Assessment agricultural soils of Acre by different experts. Rev. Bras. Ciênc. Solo 35, 1841-1853 (in Portuguese).

Delden, H. Van, Vliet, J. Van, Rutledge, D.T., Kirkby, M.J., 2011. Comparison of scale and scaling issues in integrated land-use models for policy support. Agric. Ecosyst. Environ. 142, $18-28$.

Demattê, J.A.M., Galdos, M.V., Guimarães, R., Genú, A.M., Nanni, M.R., Zullo Jr., J., 2007. Quantification of tropical soil attributes from ETM + /Landsat-7 data. Int. J. Remote Sens. 8, 3813-3829.

Embrapa, 1997. Empresa Brasileira de Pesquisa Agropecuária. Centro Nacional de Pesquisa de Solos. Manual Methods of Soil Analysis. Rio de Janeiro (212 pp. (in Portuguese))

Embrapa, 2006. Empresa Brasileira de Pesquisa Agropecuária. Centro Nacional de Pesquisa de Solos. Sistema brasileiro de classificação de solos, 2 ed., p. 306 (Rio de Janeiro (in Portuguese))

Franzen, D.W., Nanna, T., Norvell, W.A., 2006. A survey of soil attributes in North Dakota by landscape position. Agron. J. 98, 1015-1022.

Gallardo, A., Paramá, R., 2007. Spatial variability of soil elements in two plant communities of NW Spain. Geoderma 139, 199-208.

Geobank, 2012. Serviço Geológico do Brasil - CPRM Available in: http://geobank.sa. cprm.gov.br/ (Accessed at: 10/10/2012. (in Portuguese)).

Ghidin, A.A., Melo, V.F., Lima, V.C., Costa Lima, J.M.J., 2006. Oxisol toposequences developed from basaltic rocks in Paraná State, Brazil: II - relationship between clay fraction mineralogy and physical soil properties. Rev. Bras. Ciênc. Solo 30, 345-357.

Goluchowska, B.J., 2001. Some factors affecting an increase in magnetic susceptibility of cement dusts. J. Appl. Geophys. 48, 103-112.

Guedes Filho, O., Vieira, S.R., Chiba, M.K., Nagumo, C.H., Dechen, S.C.F., 2010. Spatial and temporal variability of crop yield and some Rhodic Hapludox properties under no-tillage. Rev, Bras. Ciênc. Solo 34, 1-14.

Hall, G.F., 1983. Pedology and geomorphology, in: Hall, G.F. (Eds.), Pedogenesis and soil taxonomy. Concepts and interactions. E-Publishing Inc., New York, Elsevier Science Publication, pp. 117-140.

Hammer, R.D., Young, N.C., Wolenhaupt, T.L., Barney, T.L., Haithcoate, T.W., 1995. Slope class maps form soil survey and digital elevation models. Soil Sci. Soc. Am. J. 59, 509-519 (Madison)

Hastie, T., Tibshirani, R., Friedman, J., 2001. The elements of statistical learning: data mining, inference and prediction. Springer Series in Statistics. Springer-Verlag, New York.

Hudson, B.D., 1992. The soil survey as paradigm-based science. Soil Sci. Soc. Am. J. 56, $836-841$.

Hunt, D.R., 1995. Farm Power and Machinery Management, 9 ed. Iowa University Press, Ames, p. 365

Ibáñez, J.J., Arnold, R.W., Ahrens, R.J., 2009. The fractal mind of pedologists (soil taxonomists and soil surveyors). J. Ecol. Complex. 6, 286-293.

Instituto De Pesquisas Tecnológicas Do Estado De São Paulo (IPT), 1981. Geomorphological Map of the State of São Paulo (94 pp., (in Portuguese)).

Isaaks, E.H., Srivastava, R.M., 1989. Applied Geostatistics. Oxford University Press, Nova York (561 pp.)

Johnson, R.M., Richard Jr., E.P., 2005. Sugarcane yield, sugarcane quality, and soil variability in Louisiana. Agron. J. 97, 760-771.

Kämpf, N., Schwertmann, U., 1982. Goethite and hematite in a climosequence in Southern Brazil and their application in classification of kaolinitic soils. Geoderma 29, 27-39.

Kapicka, A., Jordanova, N., Petrovský, E., Ustjak, S., 2001. Effect of different soil conditions on magnetic parameters of power-plant fly ashes. J. Appl. Geophys. 48, 93-102 (Amsterdam).

Kravchenko, A.N., Bullock, D.G., 2002. Correlation of corn and soybean yield with topography and soil properties. Agron. J. 75, 75-83.

Lagacherie, P., Legros, J.P., Burrough, P.A., 1995. A soil survey procedure using the knowledge of soil patterns established on a previously mapped reference area. Geoderma 65, 283-301.

Legros, J.-P., 2006. Mapping of the Soil, p. 411.

Lehner, B., Verdin, K., Jarvis, A., 2006. HydroSHEDS Technical Documentation. World Wildlife Fund US, Washington, DC (26 pp. Available in: <http://hydrosheds.cr.usgs.gov>).

Li, J., Heap, A.D., 2008. A Review of Spatial Interpolation Methods for Environmental Scientists. Geoscience Australia, p. 137.

Li, Y., Shi, Z., Wu, C., Li, H., Li, F., 2007. Improved prediction and reduction of sampling density for soil salinity by different geostatistical methods. Agric. Sci. China 6, 832-841.

Lu, A.J., Wang, X., Oin, K., Wang, P.H., Zhang, S., 2012. Multivariate and geostatistical analyses of the spatial distribution and origin of heavy metals in the agricultural soils in Shunyi, Beijing, China. Sci. Total Environ. 425, 66-74.

Machado, P.L.O.A., Bernardi, A.C.C., Valencia, L.I.O., Molin, J.P., Gimenez, L.M., Silva, C.A. Andrade, A.G.A., Madari, B.E., Meirelles, M.S.P.M., 2006. Mapping of electrical conductivity and relationship with clay Oxisol under no-tillage. Pesq. Agrop. Brasileira 41, 1023-1031 (in Portuguese).

Maher, B.A., Thompson, R., 1999. Palaeomonsoons I: The Magnetic Record of Palaeoclimate in the Terrestrial Loess and Palaeosol Sequences, in Quaternary Climates, Environments and Magnetism. University Press, Cambridge, pp. 81-125. 
Marcos, Z.Z., 1982. Ensaio sobre epistemologia pedológica. Cah. Pédol. 19, 5-28 (in Portuguese).

Marques Jr., J., Lepsch, I.F., 2000. Depósitos superficiais neocenozóicos, superfícies geomórficas e solos Monte Alto, SP. Geociências 19, 90-106.

Marques Jr., J., Siqueira, D.S., Camargo, L.A., Teixeira, D.B., Barrón, V., Torrent, J., 2014. Magnetic susceptibility and diffuse reflectance spectroscopy to characterize the spatial variability of soil properties in a Brazilian Haplustalf. Geoderma 219, 63-71.

Martins Filho, M.V., Liccioti, T.T., Pereira, G.T., Marques Jr., J., Sanchez, R.B., 2009. Perdas de solo e nutrientes por erosão num Argissolo com resíduos vegetais de cana-de-açúcar. Eng. Agríc. 29, 8-18 (in Portuguese)

Matias, S.S.R., Marques Jr., J., Siqueira, D.S., Pereira, G.T., 2013. Modelos de paisagem e susceptibilidade magnética na identificação e caracterização do solo. Pesqui. Agrop. Trop. 43, 93-103 (in Portuguese).

McBratney, A., Mynasny, B., Stephen, R., Cattle, R., Vervoort, Willem, 2002. From pedotransfer functions to soil inference systems. Geoderma 109, 41-73.

Mestdagh, M.M., Vielvoye, L., Herbillon, A.J., 1980. Iron in kaolinite II: the relationship between kaolinite cristalinity and iron content. Clay Miner. 15, 1-13.

Mialhe, L.G., 1974. Manual of Agricultural Mechanization. Agronômica Ceres, São Paulo (301 pp. (in Portuguese)).

Michel, F.M., Barrón, V., Torrent, J., Morales, M.P., Serna, C.J., Boilye, J.F., Liu, Q.S., Ambrosinig, A., Cismasu, A.C., Brown, G.E., 2010. Ordered ferrimagnetic form of ferrihydrite reveals links between structure, composition and magnetism. Proc. Natl. Acad. Sci. U. S. A. 107, 2787-2792.

Minasny, B., McBratney, A.B., 2007. Estimating the water retention shape parameter from sand and clay content. Soil Sci. Soc. Am. 71, 105-1.110.

Minasny, B., Alex, B., McBratney, A.B., Hartemink, A.E., 2010. Global pedodiversity, taxonomic distance, and the World Reference Base. Geoderma 155, 132-139.

Montanari, R., Souza, G.S.A., Pereira, G.T., Marques Jr., J., Siqueira, D.S., Siqueira, G.M., 2012. The use of scaled semivariograms to plan soil sampling in sugarcane fields. Precis. Agric. 13, 01-11.

Montgomery, D.R., 2003. Predicting landscape scale erosion rates using digital elevation models. Compt. Rendus Geosci. 335, 1121-1130.

Pereira, G.T., Marques Júnior, J., Lepsch, I.F., Barbosa, J.C., 1996. JEM 1.0: programa computacional para localização de limites de superfícies geomórficas de solos através de dados de uma transeção; caso univariado. Congresso Latino Americano de Ciência do Solo (in Portuguese).

Plaçon, A., Tchoubar, C., 1977. Determination of structural defects in phyllosilicates by $\mathrm{X}$-ray powder diffraction: II: nature and proportion of defects in natural kaolinites. Clay Clay Miner. 25, 436-450.

Raij, B. Van, Zullo, M.A.T., 1977. Métodos de análises de solo. Instituto Agronômico, Campinas (16 pp. (Circular, 63). (in Portuguese)).

Raij, B.Van, Andrade, J.C., Cantarella, H., Quaggio, J.A., 2001. Análise química para avaliação da fertilidade de solos tropicais. Instituto Agronômico, p. 258 (in Portuguese).

Rauch, J.N., 2011. Global distributions of $\mathrm{Fe}, \mathrm{Al}, \mathrm{Cu}$, and $\mathrm{Zn}$ contained in Earth's derma layers. J. Geochem. Explor. 110, 193-201.

Resende, M., Santana, D.P., Rezende, S.B.1988a. Susceptibilidade magnética em Latossolo do sudeste e sul do Brasil, in: Reunião de Classificação, Correlação de Solos e Interpretação de Aptidão Agrícola. E-Publishing Inc., Rio de Janeiro: EMBRAPA-SNLCS/SBCS, pp. 233-258. (in Portuguese).

Resende, M., Santana, D.P., Franzmeier, D.P., Coey, J.M.D., 1988a. Magnetic properties of Brazilian Oxisols. International Soil Classification Workshop, Rio de Janeiro, pp. 78-108 (in Portuguese).

Rockström, J., Steffen, W., Noone, K., Persson, A., Chapin, F.S., Lambin, E.F., Lenton, T.M., Scheffer, M., Folke, C., Schellnhuber, H.J., Nykvist, B., Wit, C.A., Hughes, T., van der Leeuw, S., Rodhe, H., Sörlin, S., Snyder, P.K., Costanza, R., Svedin, U., Falkenmark, M., Karlberg, L., Corell, R.W., Fabry, V.J., Hansen, J., Walker, B., Liverman, D., Richardson, K., Crutzen, P., Foley, J.A., 2009. A safe operating space for humanity. Nature 461, 472-475.

Rossi, R.E., Mulla, D.J., Journel, A.G., Franz, E.H., 1992. Geostatistical tools for modeling and interpreting ecological spatial dependence. Ecol. Monogr. 62, 277-314.

Ruellan, A., Dosso, M., Fritsh, E., 1989. L'analyse structurale de la couverture pédologique. Sci. Sol 27, 319-334 (in French).

Sanchez, R.B., Marques Jr., J., Pereira, G.T., Souza, Z.M., Martins Filho, M.V., 2009. Variabilidade espacial de atributos do solo e de fatores de erosão em diferentes pedoformas. Bragantia 68, 873-884 (in Portuguese)

Sanchez, R.B., Marques Jr., J., Pereira, G.T., Neto, J.B., Siqueira, D.S., Souza, Z.M., 2012a. Mapeamento das formas do relevo para estimativa de custos de fertilização em cana-de--açúcar. Eng. Agríc. 32, 280-292 (in Portuguese).

Sanchez, M.G.B., Marques Jr., J., Siqueira, D.S., Camargo, L.A., Pereira, G.T., 2012b. Delineation of specific management areas for coffee cultivation based on the soil relief relationship and numerical classification. Precis. Agric. 14, 201-214.

Santana, D.P., 1984. Soil formation in a toposequence of oxisols from Patos de Minas Region, Minas Gerais State, Brazil 129 f. Thesis (Ph.D) Purdue University, West Lafayette.

Santos, H.L., Marques Jr., J., Matias, S.S.R., Siqueira, D.S., Pereira, G.T., 2013. Erosion factors and magnetic susceptibility in different compartments of a slope in Gilbués-PI, Brazil. Eng. Agric. 33, 64-74.
Schloeder, C.A., Zimmerman, N.E., Jacobs, M.J., 2001. Comparison of methods for interpolating soil properties using limited data. Soil Sci. Soc. Am. J. 65, 470-479.

Schulze, D.G., 1984. The influence of aluminium on iron oxides VIII. Unit-cell dimension of Al-substituted of goethites and estimation of Al from them. Clay Clay Miner. 32, 6-44.

Siqueira, D.S., Marques Jr., J., Pereira, G.T., 2010a. The use of landforms to predict the variability of soil and orange attributes. Geoderma 155, 55-66.

Siqueira, D.S., Marques Jr., J., Matias, S.S.R., Barrón, V., Torrent, J., Baffa, O., Oliveira, L.C. 2010b. Correlation of properties of Brazilian Haplustalfs with magnetic susceptibility measurements. Soil Use Manag. 26, 425-431.

Siqueira, D.S., Marques Jr., J., Pereira, G.T., Barbosa, R.S., Teixeira, D.D.B., Peluco, R.G., 2014. Sampling density and proportion for the characterization of the variability of Oxisol attributes on different materials. Geoderma 232, 172-182.

Soil Survey Staff, 1975. A basic system of soil classification of making and interpreting soil surveys. Washington, (USDA. Agriculture Handbook, 436), 1st ed. USDA-Natural Resources Conservation Service, p. 869 (Available in: <ftp://ftp-fc.sc.egov.usda.gov/ NSSC/Soil_Taxonomy/tax.pdf >, Acessed: 10/04/2013).

Swanson, D.K., 1993. The soil survey as paradigm-based science. Soil Sci. Soc. Am. J. 57, 1164

Thornthwaite, C.W., 1948. An approach towards a rational classification of climate. Geogr. Rev. 38, 55-94.

Torrent, J., Barrón, V., Liu, Q.S., 2006. Magnetic enhancement is linked to and precedes hematite formation in aerobic soil. Geophys. Res. Lett. 33, 1-4.

Torrent, J., Liu, Q.S., Bloemendal, J., Barrón, V., 2007. Magnetic enhancement and iron oxides in the upper Luochuan loess-paleosol sequence, Chinese Loess Plateau. Soil Sci. Soc. Am. J. 71, 1-9.

Torrent, J., Liu, Q.S., Barrón, V., 2010. Magnetic minerals in Calcic Luvisols (Chromic) developed in a warm Mediterranean region of Spain: origin and paleoenvironmental significance. Geoderma 154, 465-472.

Trangmar, B.B., Yost, R.S., Uehara, G., 1985. Application of geostatistics to spatial of soil properties. Adv. Agron. 38, 45-94.

Troeh, F.R., 1965. Landform equations fitted to contour maps. Soil Sci. Soc. Am. J. 263 616-627.

Vasconcelos, V., Carvalho Junior, O.A., Martins, E.S., Couto Júnior, A.F., Guimaraes, R.F., Gomes, R.A.T., 2012. Sistema de classificação geomorfométrica baseada em uma arquitetura sequencial em duas etapas: árvore de decisão e classificador espectral, no Parque Nacional da Serra da Canastra. Rev. Bras. Geomorfol. 13, 171-186 (in Portuguese).

Vasconcelos, V., Martins, E.S., Carvalho Jr., O.A., Marques Jr., J., Siqueira, D.S., Couto Jr., A.F., Guimaraes, R.F., Gomes, R.A.T., Reatto, A., 2013. Modelo de Evolução Pedogeomorfológica da Serra da Canastra, MG. Rev. Bras. Geomorfol. 14 197-212 (in Portuguese).

Verosub, K.L., Roberts, A.P., 1995. Environmental magnetism: past, present and future J. Geophys. Res. 100, 2175-2192.

Vidal-Torrado, P., Lepsch, I.F., Castro, S.S., 2005. Concepts and Applications of Relations Geomorphology Pedology in Moist Tropical Regions, in: Vidal-Torrado, P., Ferraciu, L.R., Cooper, M., Cardoso, E.J., Prochonow, L. (Eds.), Tópicos em Ciência do Solo. E-Publishing Inc., Viçosa, Sociedade Brasileira de Ciência do Solo, pp. 145-192. (in Portuguese).

Vieira, S.R., 2000. Geostatistics in spatial variability of soil, in: Novais, R. F., Alvarez, V. V. H., Schaefer, C. E. G. R. (Eds.), Tópicos em Ciência do Solo. E-Publishing Inc., Viçosa, Sociedade Brasileira de Ciência do Solo, pp. 1-54. (in Portuguese).

Vieira, S.R., Carvalho, J.R.P., Paz-González, A., 2010. Jack knifing for semivariogram validation. Bragantia 69, 97-105 (in Portuguese).

Viscarra Rossel, R.A., Bui, E.N., Caritat, P. De, Mckenzie, N.J., 2010. Maping iron oxides and the color of Australian soil using visible-near-infrared reflectance spectra. J. Geophys. Res. Earth Surf. 115, 1-13.

Voltz, M., Webster, R., 1990. A comparison of kriging, cubic splines and classification for predicting soil properties from sample information. J. Soil Sci. 41, 473-490.

Webster, R., 1973. Automatic soil-boundary location from transect data. Math. Geol. 5, 27-37.

Webster, R., 1978. Optimally partitioning soil transects. Soil Sci. Soc. Am. J. 29, 388-402.

Wu, Y., Slater, L., Versteeg, R., Labrecque, D., 2008. A comparison of the low frequency electrical signatures of iron oxide versus calcite precipitation in granular zero valent iron columns. J. Contam. Hydrol. 95, 154-167.

Wyszecki, G., Stiles, W.S., 1982. Color Science: Concepts and Methods, Quantitative Data and Formulae, 2nd ed. John Wiley \& Sons, New York, p. 976.

Zawadzki, J., Cieszewski, C.J., Zasada, M., Love, R.C., 2005. Applying geostatistics for investigations of forest ecosystems using remote imagery. Silva Fenn. 39, 559-617.

Zawadzki, J., Magiera, T.z., Fabijanczyk, P., 2012. Geostatistical 3-dimensional integration of measurements of soil magnetic susceptibility. Environ. Monit. Assess. 184, 3267-3278

Zullo Jr., J., 1994. Correção atmosférica de imagens de satélite e aplicações 189 f. Tese (Doutorado em Engenharia Elétrica) - Faculdade de Engenharia Elétrica. Universidade Estadual de Campinas, Campinas (in Portuguese). 